\title{
THE MESOLITHIC LITHIC INDUSTRIES OF THE EASTERN ADRIATIC ZONE
}

\author{
Malgorzata Kaczanowska, Janusz K. KozŁowski
}

A u t h o r s' a d d r e s s: The Polish Academy of Arts and Sciences, Sławkowska 17, 31-016 Kraków, Poland, e-mails: malgorzatakacz@wp.pl,janusz.kozlowski@uj.edu.pl

A b s tract. In the Mesolithic, specific traits of the environment of the eastern Adriatic coast resulted in the emergence of a local cultural province, different from the Central Balkans and open to trans-Adriatic influences. This province was distinguished by the blending of three different cultural traditions: Epigravettian, Sauveterian, and Castelnovian.

K e y w o r d s: Eastern Adriatic, Epigravettian, Sauveterian, Castelnovian, flake-blade inventories

\section{INTRODUCTION}

The objective of this paper is to analyse the taxonomy of Early Holocene units situated on the eastern Adriatic coast. Such an analysis is an indispensable base for the reconstruction of a variety of processes that contributed to the Neolithisation of the Balkans. Sites with Mesolithic levels registered in Slovenia, Croatia, Montenegro, Albania and north-western Greece (Fig. 1) will be discussed. These are open-air sites, cave and rock-shelter sites and sites registered in surface surveys. Some of them are multilayer sites where Mesolithic layers are stratified in between layers dated to the end of the Palaeolithic and the Early Neolithic. It should be added that the documentation of the sites is frequently incomplete because the major bulk of the archaeological finds come from old investigations. One should also note that the materials from past research are hardly accessible and we cannot be sure whether they correspond to assemblages retrieved during more recent excavations. In some cases, new research has allowed for a more comprehensive picture of assemblages (e.g. in Crvena stijena, WHALlon ed. 2017).

In the analysis of lithic assemblages a uniform system of classification based on technological and morphological features will be used. We are aware that such a system may raise objections as overly formalised, but the results obtained thus far can only be verified through new research. 


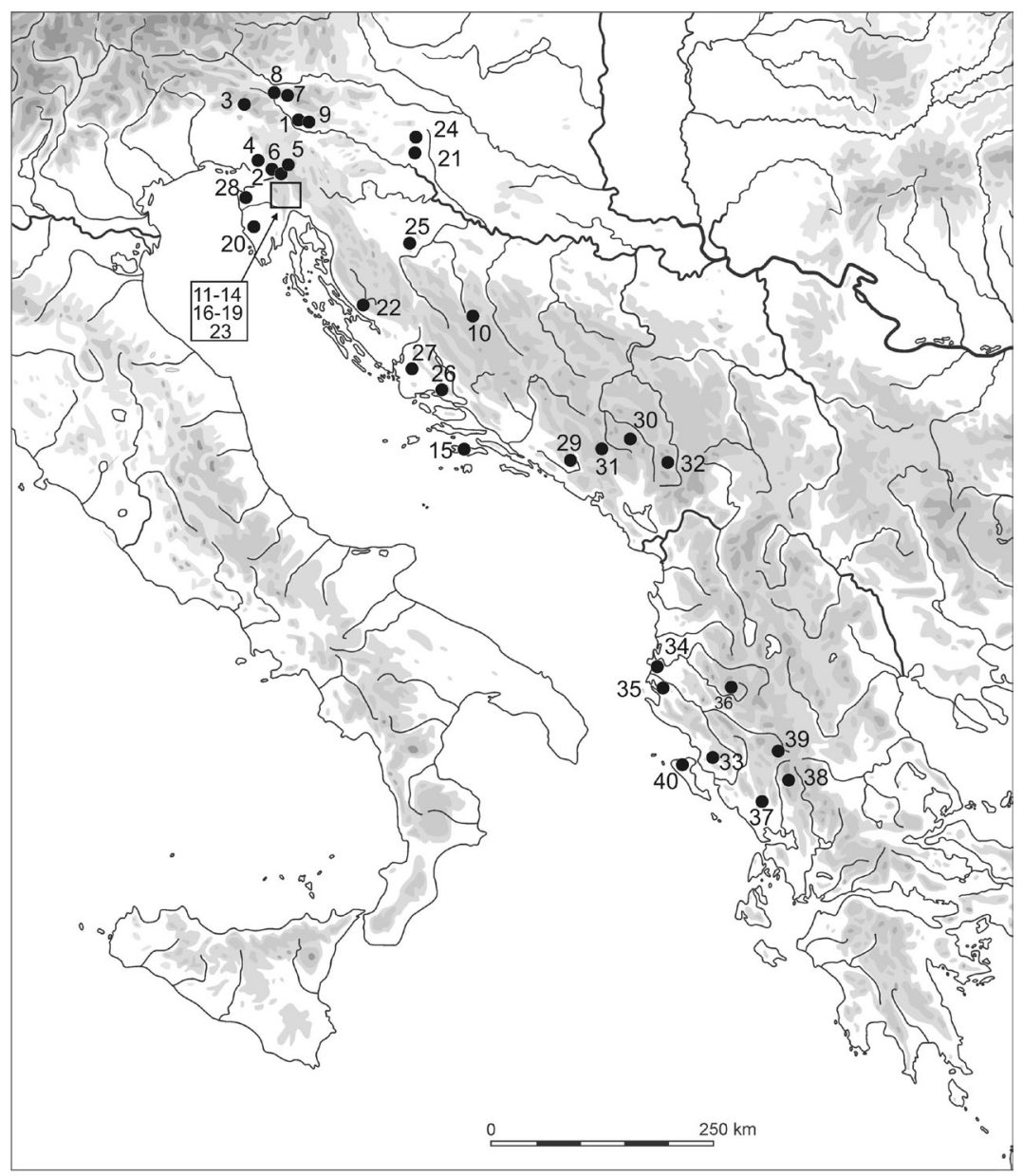

Fig. 1. Map of the sites discussed in the paper: 1 - Breg; 2 - Dedkov Trebež; 3 - Pretovč; 4 - Mala Triglavca; 5 - Pod Črmukljo; 6 - Viktoriev spodmol; 7 - Vrbicev Hrbec; 8 - Zalog; 9 - Zamedvedca; 10 - Rastuša; 11 - Abri Šebrn; 12 - Bragujčeva loza; 13 - Jačmica cave; 14 - Klanjčeva cave; 15 - Kopačina cave; 16 - Lokve; 17 - Nugljanska cave; 18 - Ovčja cave; 19 - Pupićina cave; 20 - Rovinjsko selo cave; 21 - Šupljata cave; 22 - Vaganačka pec; 23 - Vela pec; 24 - Velika pec; 25 - Zala cave; 26 - Zemunica cave; 27 - Podumci; 28 - Savudrija; 29 - Crvena stjena; 30 - Odmut; 31 - Medena stjena; 32 - Trebački krš; 33 - Konispol; 34 - Putanja - Portonov; 35 - Kryegata B; 36 - Vlusha; 37 - Aspochaliko; 38 - Kastritsa; 39 - Klithi; 40 - Sidari

We were unable to build a complete list of technological characteristics - it was restricted to the characteristic features of cores and some features of blanks. The use of specific techniques of tool manufacture to shape tool preforms (e.g. the microburin technique and the relation of the retouched edges with the blank axes) have been also taken into consideration. Thus, the classification system has been based on similar criteria to those applied in A. Broglio, S.K. KozŁowsKi (1983). Furthermore, attempts have been made to implement a more recent approach to the materials, in particular concerning the manufacture of blanks. An important aspect of analysis of 
tool inventories has been the reconstruction of the relations between the production areas and the zones where the artefacts were used.

The question of the origin of exploited raw materials will be a subject of a separate publication, after a series of petrographic analyses is completed.

\section{THE MOST IMPORTANT MESOLITHIC TECHNOCOMPLEXES IN THE CIRCUM-ADRIATIC ZONE}

Authors of studies on the regional classification of the Mesolithic of south-eastern Europe (J.K. KozŁowski, S.K. KozŁowsKi 1983; A. Broglio, S.K. KozŁowsKi 1983; S.K. Kozlowski 2009; Cristiani, Borić 2016) have distinguished the south-east European province (S.K. Kozłowski 2009: 218) where the most important taxonomic unit is the Epigravettian, adjacent to the Sauveterrian from the west. The Epigravettian technocomplex evolved from the tradition of the local Terminal Palaeolithic. The development of this cultural complex came to an end with the emergence of the Castelnovian (S.K. KozŁowsKi 2009: 432). The circum-Adriatic evolution of cultural units was not continuous in its nature. It was rather a partially parallel evolution of the local tradition (Epigravettian) and trans-Adriatic units (Sauveterrian, Castelnovian) emergent as a result of trans-Adriatic contacts. This diversity in the region in question is not only the effect of a variety of cultural traditions, but it also reflects differences in types and functions of sites, i.e. open-air sites, cave sites, workshops, short-term camps, and living sites (Broglio, LANZINGER 1996).

\section{The Epigravettian}

The Epigravettian is the continuation of the Gravettian/Perigordian tradition. Most researchers tend to see the transitional moment in the period after the Upper Pleniglacial. Thus the development of this taxonomic unit spans a long period of the Terminal Glacial and the beginning of the Holocene, embracing the territories of the Northern Mediterranean, from Iberia to western Anatolia (Montet-White, KozŁowski J. K. 1983; S. K. KozŁowsKi 1999; J. K. KozŁowsKi, KaCzanowsKa 2004; MinaJlović, MinAJLOVIĆ 2007). The most complete Epigravettian sequences are known from the territory of Italy, notably from Apulia (Paglici Cave - PALma Di Cesnola 1993, 2005). A distinctive feature of the evolution of the Epigravettian in southern Italy are the Early Epigravettian horizons, directly following the maximum of the Upper Pleniglacial (19 000-15 000 years BP) with leaf points and shouldered points, and, subsequently the Late Epigravettian layers in the Bölling and Alleröd with microgravettes, geometrical inserts (triangles, segments) and with the microburin technique (Lo VeTRO, MARTINI 2012). The development of the Epigravettian ended in Italy, particularly in Apulia with the Romanellian, corresponding to the final Epigravettian, distributed primarily in Liguria, including South-Eastern France, where this unit contributed to the formation of the Romanello-Azilian (Escalon De Fonton 1966). 
On the eastern coast of the Adriatic, relatively few sites with long Epigravettian sequences have been discovered, and, regretfully, they have not provided absolute age determinations. Among these sites belongs, most importantly, the Crvena Stijena Cave (Montenegro) where lithic industry in layers VIII, VII, VI and V consisted of arched backed pieces (Pl. 1: 1), discoidal (Pl. 1: 2, 3) and subdiscoidal (Pl. 1:4) end-scrapers, and truncations (Pl. 1: 5) (BASLER 1975: Pl. 9-13). This industry is a continuation of a similar tradition from layers X and IX at this site, but it exhibits increasing microlithization. In layer IV at Crvena stijena (IVb2, IVb1, IVa), which can, in all likelihood, be placed at the Early Holocene, the flake technique (Pl. 1: 6-8) is accompanied by new blade Castelnovian components such as bladelets (P1. I: 9-12), strangled pieces (Pl. 1: 13-15) and trapezes (Pl. 1: 16, 17) (BASLER 1975: Pl. 1, 2). Flint industries are accompanied by numerous objects made of bone and red deer antler. Changes such as the increased role of the flake technique and the using of lower-quality raw materials are explained by the authors of the most recent study (MinaJlović 2001; MiHAJlović et al. 2017) as adaptation to a changing environment and reduced mobility of human groups.

Another important eastern Adriatic sequence is the Medena Stijena Cave (Montenegro - MinaJlović 1996). The Epigravettian layers VII-V contained, predominantly, backed pieces (Pl. 2: 1-13) and geometric microliths (mainly triangles - Pl. 2: 14-19). A distinct techno-typological change takes place in layer IV with a flake industry (end-scrapers - Pl. 2: 20, 21 and retouched flakes Pl. 2: 22-24) and single trapezes (Pl. 2: 25, 26) (MinAJlović 1996: Pl. XI). Just as at Crvena Stijena, the change occurred most probably at the Pleistocene/Holocene boundary.

Numerous eastern Adriatic sites yielded single Epigravettian levels that correspond to the Pleistocene/Holocene transition and to the Early Holocene. In Slovenia, surface surveys revealed the site of Vrbicev Hrbec, where arched backed pieces, scalene triangles and truncations made on regular blade blanks were collected. At other sites in Slovenia Epigravettian elements (simple backed pieces, segments, triangles, arched backed pieces) co-occur with Castelnovian components (Montbani bladelets, trapezes, regular blades). Inventories of this type were registered e.g. at Dedkov Trebež (Pl. 3: 1-9) and Zamedvedca (BRODAR, Osole 1979; S.K. KozŁowsKi 2009). Similar Late Epigravettian or Castelnovian tool types are known from Breg (FreliH 1986, 1987) where the Mesolithic level (Pl. 3: 10-24) has been dated to $9180 \pm 50 \mathrm{BP}$ (base) and $6830 \pm 150 \mathrm{BP}$ (top) (MLekUž 2001).

Sites with the Epigravettian tradition are more numerous (DimitRIJEvić 1998; Paunović, Karavanić 1997) in the territory of Croatia (Pupićina Cave - Miracle, Forenbaher 2006; Vela Cave - Miracle, Forenbaher 1998; Ovčja Cave - Komšo, Miracle 2003; Malez 1960; Bragujčeva Cave - Malez 1974; Klanjčeva Cave - Malez 1974; Jačmica Cave - Komšo, Miracle 2005, 2006; Rovinjsko selo Cave - Komšo 2003, 2006; Kopačina Cave on the island of Brač - ČeČUK 1986, 1996; Zala Cave - VuKosAVLJEvić, KARAVANIĆ 2015). All these sites provided single-platform flake and blade cores (Pl. 4: 1-4), blades and crested blades (Pl. 4: 6), splintered pieces (Pl. 4: 7, 8), end-scrapers (Pl. 4: 9-13), burins (Pl. 4: 5), backed pieces (Pl. 4: 14), the microburin technique, and at some sites also perforators (Pl. 4: 15). Chronologically they can be placed at the 


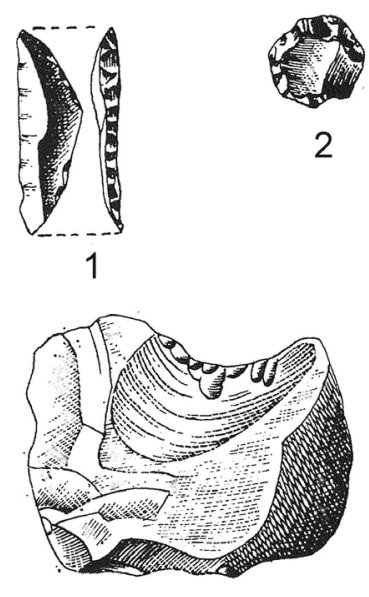

6

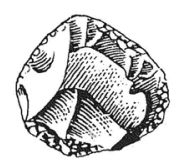

3

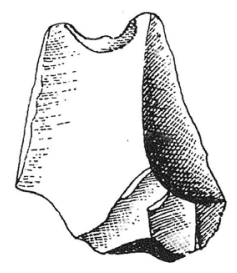

7
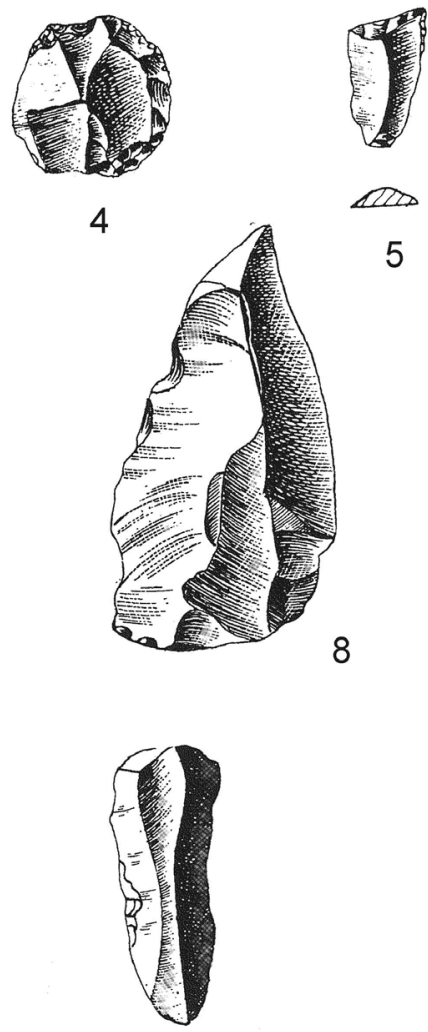

12

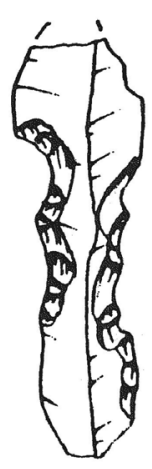

13

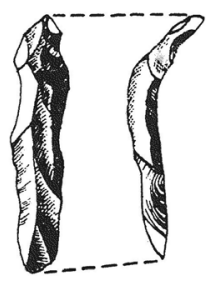

10

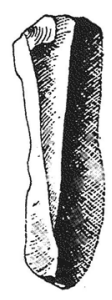

11
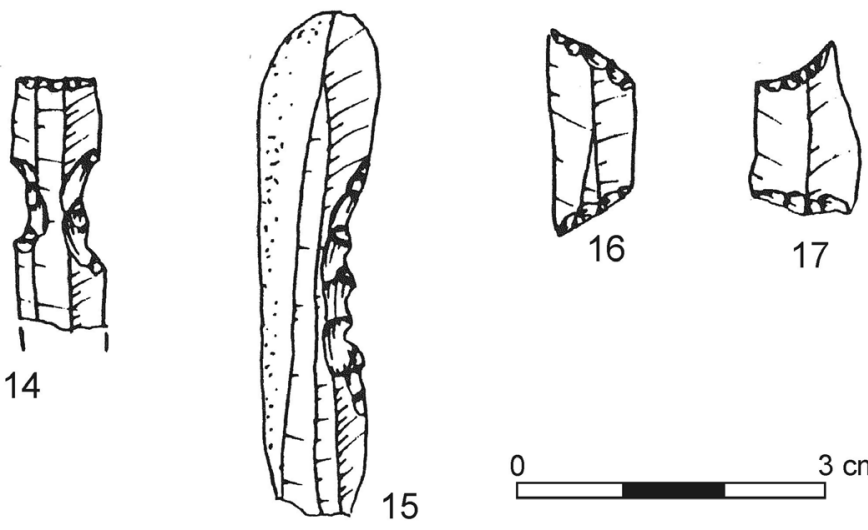

14

15

Pl. 1. 1-17. Crvena stijena, Montenegro (according to BRODAR 1979 and BAKović et al. 2009)

Pleistocene/Holocene transition (Pupićina Cave - 10 000-7500 cal BP, Klanjčeva Cave

- 9800-8500 BP, Kopačina Cave - $9160 \pm 100$ BP) or the Early Holocene (Zala Cave $-9430 \pm 50,9210 \pm 40 \mathrm{BP}$, Ovčja Cave - on the basis of malacofauna). 

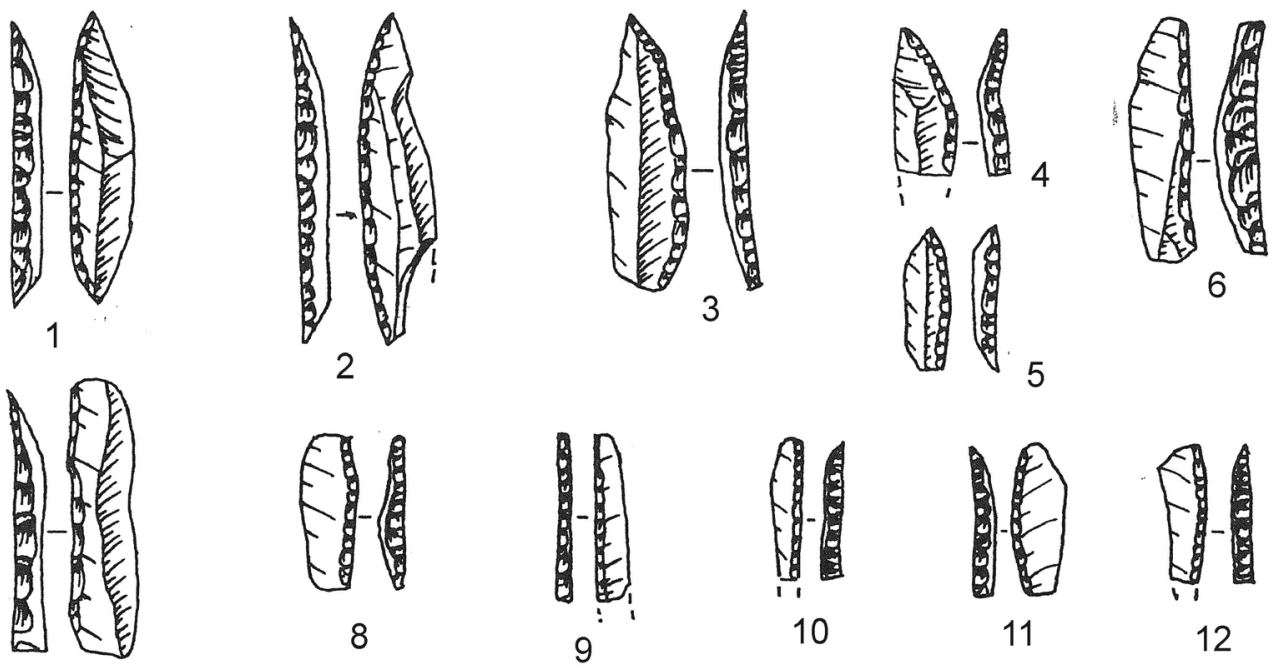

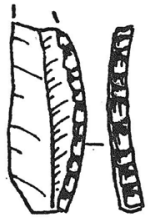

13

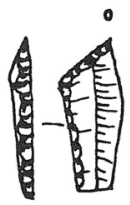

18

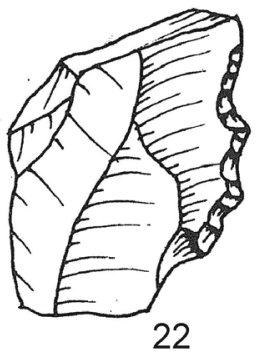

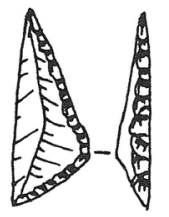

14
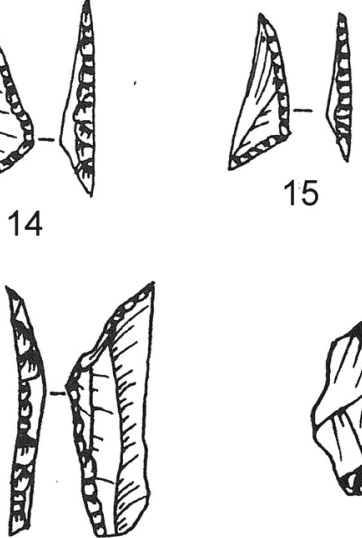

19
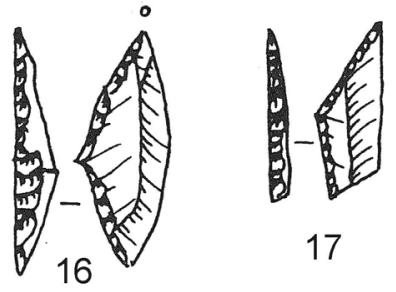

17
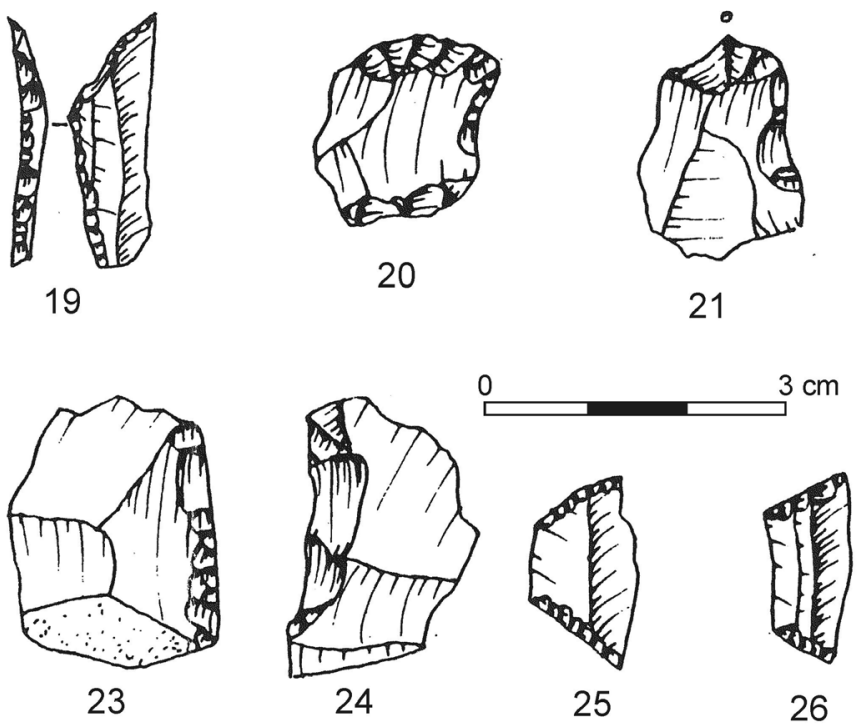

P1. 2. 1-26. Medena stijena, Montenegro (according to MiHAJlović 1996) 

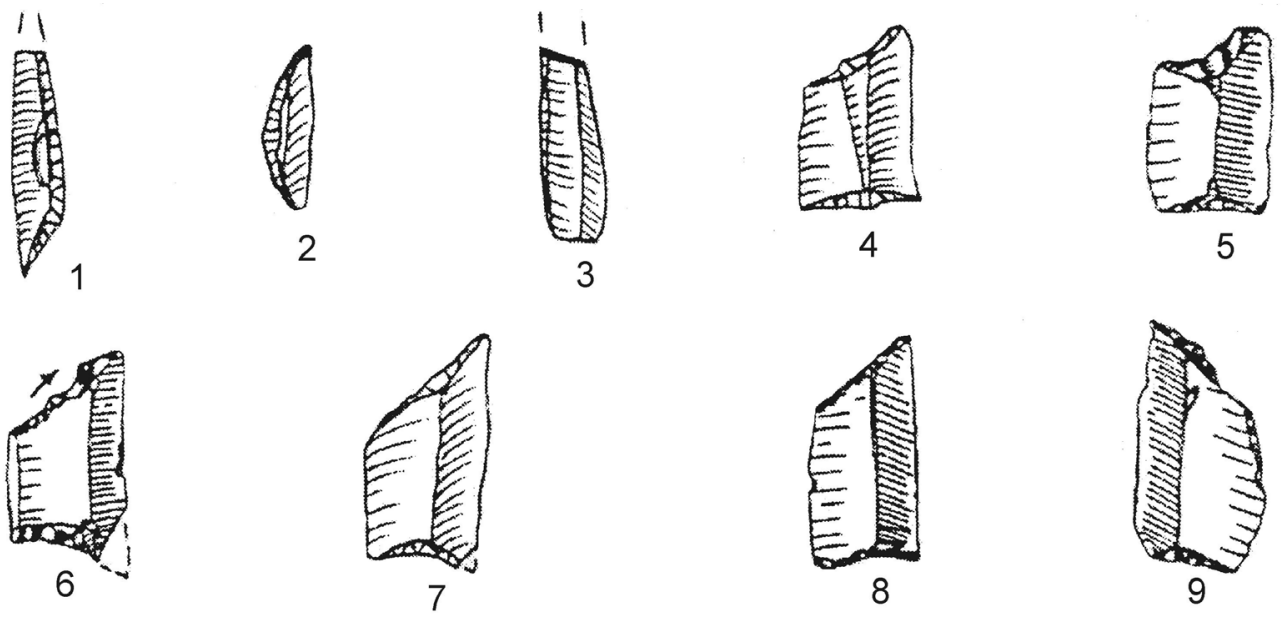

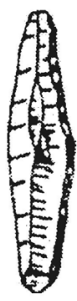

10

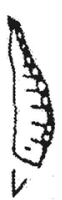

16

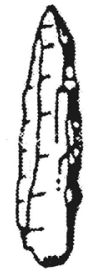

11

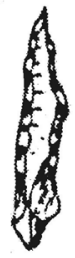

17
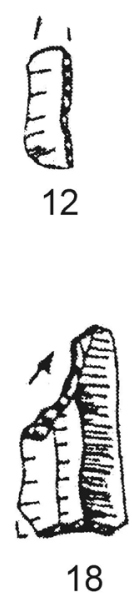
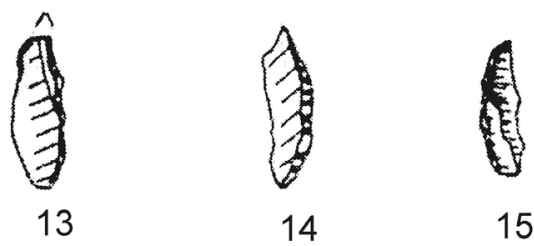
$3 \mathrm{~cm}$

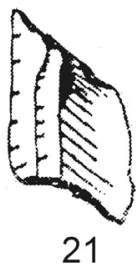

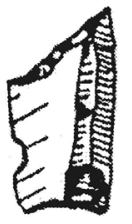

19

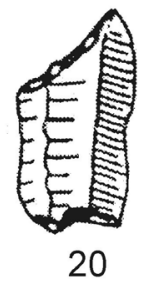

Pl. 3. 1-9. Dedkov Trebež, Slovenia; 10-24. Breg, Slovenia (according to S. K. KozŁowsKi 2009) 

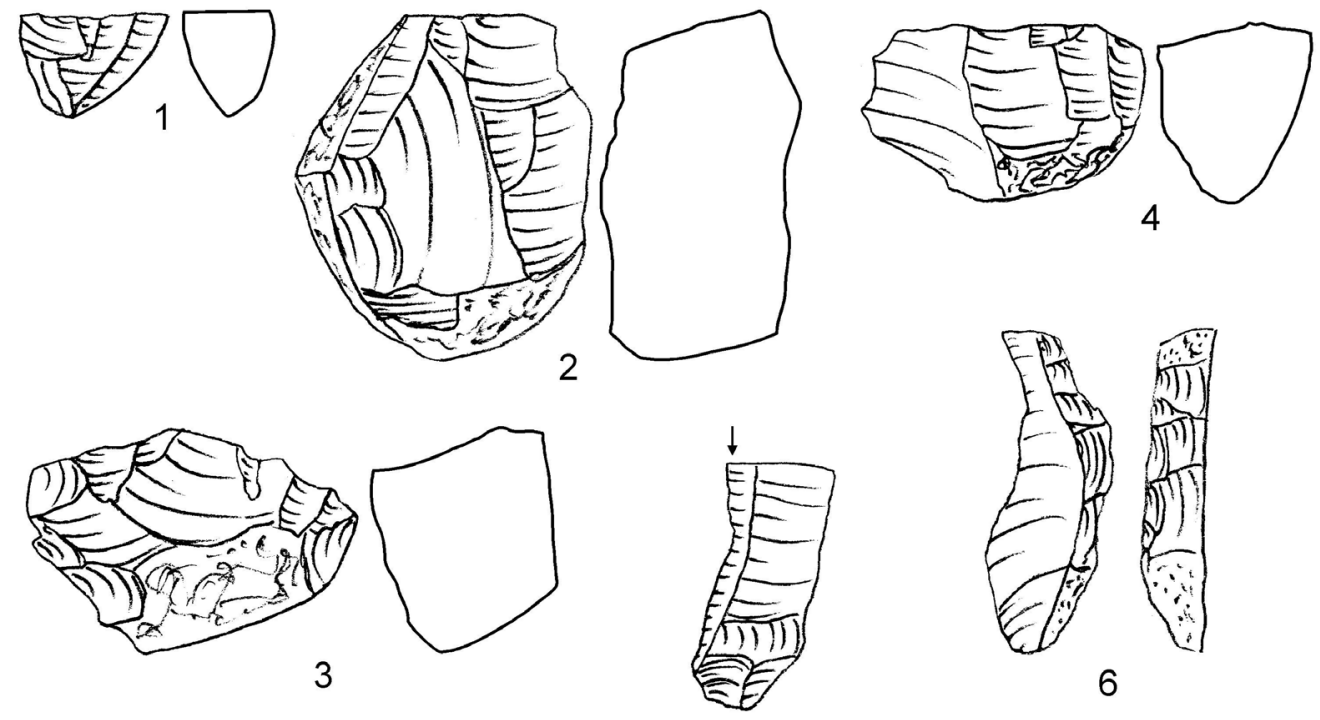

6

5
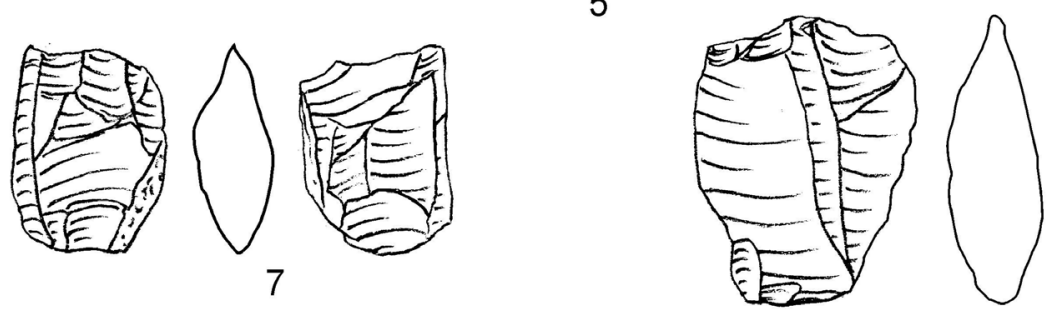

8
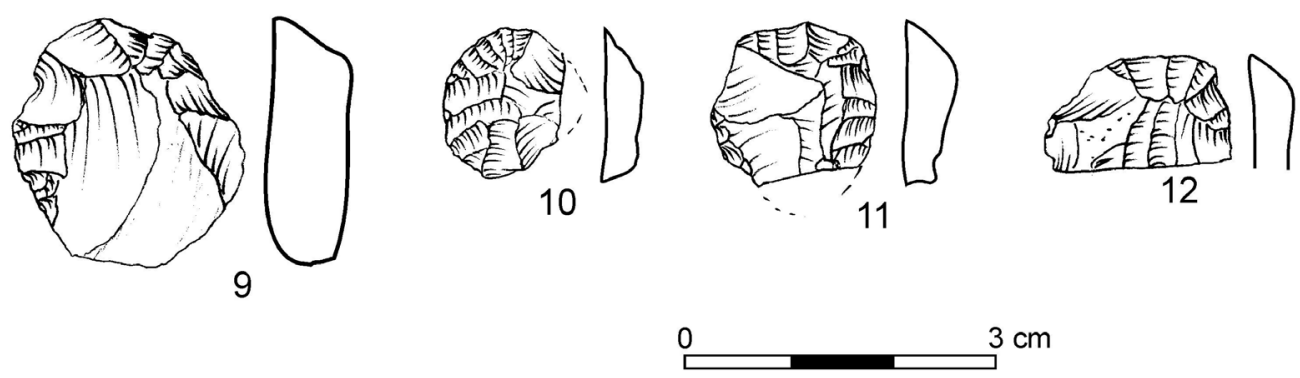

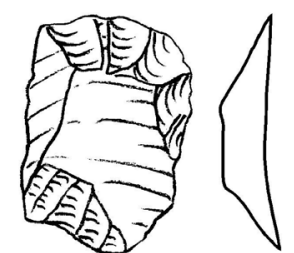

13

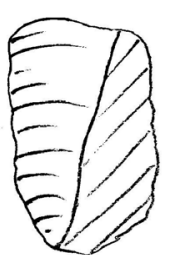

P1. 4. 1-15. Zala Cave, Croatia

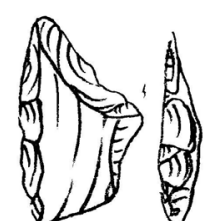

14

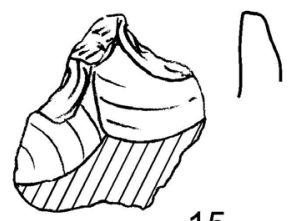

15 


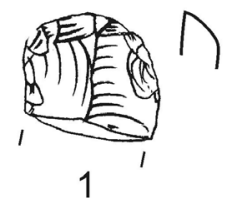

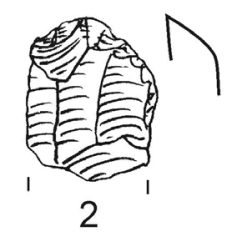
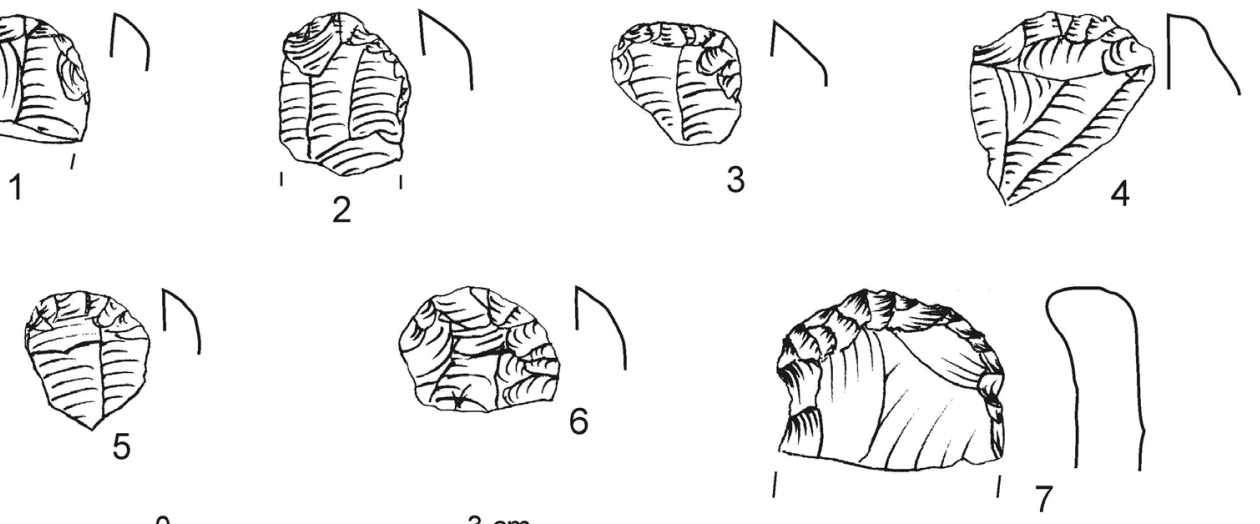

0 $3 \mathrm{~cm}$

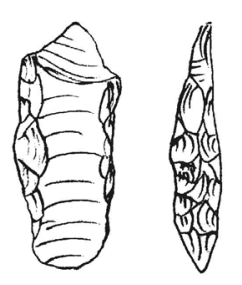

9

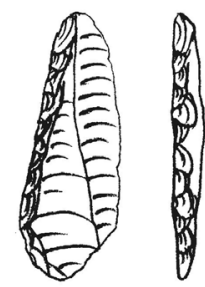

10

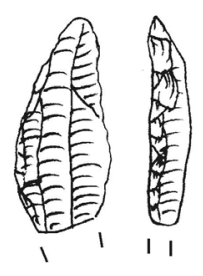

11

8

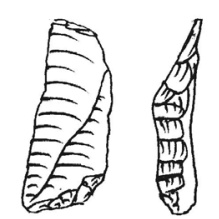

12

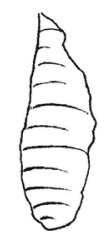

13

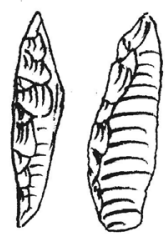

P1. 5. 1-16. Trebački krš, Montenegro

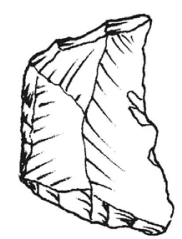

15

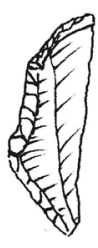

16

It should be added that the inventory from the Zala Cave was made of local radiolarites in $80 \%$, but items made of hornstone from the Upper Adige were also found (5\%) confirming the trans-Adriatic contacts.In Montenegro, in addition to the abovementioned long sequences such as Crvena Stijena and Medena Stijena, short sequences also occur, such as Trebački krš layers Ia, Ib, II (ĐurČIć 1996). The industry from this site consists of short and discoidal end-scrapers (Pl. 5: 1-7), straight (Pl. 5: 8-10) and arched (Pl. 5: 11-14) backed pieces, simple trapezes, and trapezes with retouch on three sides (Pl. 5: 15, 16).

In the territory of Albania the Epigravettian tradition was registered, first of all, in the Konispol Cave (trench XXI, layer 42) which yielded backed pieces (Pl. 6: 1), truncations (Pl. 6: 2, 3), flake (Pl. 6: 4) and blade (Pl. 6: 5) end-scrapers, and possibly also 
trapeze fragments (P1. 6: 6). The level assumed to be Epigravettian provided the date of $7430 \pm 80$ BP. Level 49 provided a similar date in the same trench $(7550 \pm 80 \mathrm{BP})$ (SCHUldenReIn 1998). The site of Putanja-Portonov - (RuKA et al. 2014) in Albania could possibly be also attributed also to the Epigravettian. The site yielded truncations (Pl. 6: 7, 8), segments (Pl. 6: 9), simple (Pl. 6: 10) and angulated (Pl. 6: 11) backed pieces, and possibly trapeze fragments (Pl. 6: 12). However, the homogeneity of the site is uncertain (Pl. 6: 13, 14). Assuming the dates from Konispol Cave are correct, the Epigravettian in the territory of Albania would, then, have persisted longer than in the territories further north (Montenegro, Croatia). To the south, on the Ionian Sea coast, typical Epigravettian sites have not been discovered. In continental Greece only Early Epigravettian sites are known (Klithi, Kastritsa, Asprochaliko - BAILEY 1997, 1999; Bailey, Gamble 1990).

The Epigravettian sequences on the eastern Adriatic coast end with the change in technological tradition (Sauveterrian, Castelnovian), probably at the beginning of the Holocene. In several sites in this territory, the Epigravettian tradition lasted longer (MiHaJlović 2017).

\section{The Sauveterrian}

Along the eastern Adriatic coast one can observe the Sauveterrian, whose main province is northern Italy and France. The distinctive features of the Sauveterrian are small microlithes, including scalene triangles, also with retouch on three edges, Sauveterrian points, isosceles triangles, crescents, rectangles, and small backed points (S. K. KozŁOWSKI 2009) in association with numerous end-scrapers, slender or short. In the Apennine Peninsula, the classic Sauveterrian does not occur south of Naples. It is replaced there by "Mesolithico indiferenziato", a local facies of Epigravettian/Romanellian.

On the eastern Adriatic coast sites that show Sauveterrian influences are relatively few. Moreover, Sauveterrian components in inventories frequently occur together with Epigravettian, and especially Castelnovian, elements.

In Slovenia, Sauveterrian sites contained Castelnovian components as well. For example, at the site of Viktorjev spodmol (TURK 2004 (Ed.); S. K. KozŁowsKi 2009) isoscele triangles, Montclus triangles, asymmetrical trapezes and rectangles were found along with Sauveterrian points. The co-occurrence of Sauveterrian and Castelovian elements is particularly well registered at the site of Pod Črmukljo (BRODAR 1992), where in addition to typical, small Sauveterrian points, simple and arched backed points $(\mathrm{Pl} .7$ : 1-6, 13) and scalene triangles (Pl. 7: 8-12), regular bladelets with notches (Montbani bladelets) and numerous, symmetrical and asymmetrical (Pl. 7: 14-22) trapezes shaped by the microburin (Pl. 7: 23-31) technique were also recorded. These finds were accompanied by short and discoidal end-scrapers (S. K. KozŁowsKi 2009: Fig. 7.2a, 7.2b). In the case of Slovenian sites, notably surface sites or sites investigated in the past, the possibility that inventories are not homogeneous cannot be excluded.

In Croatia, Nugljanska Cave and Šupljata Cave can be assigned to sites containing Sauveterrian elements. Nugljanska Cave provided a small inventory of 17 tools, 

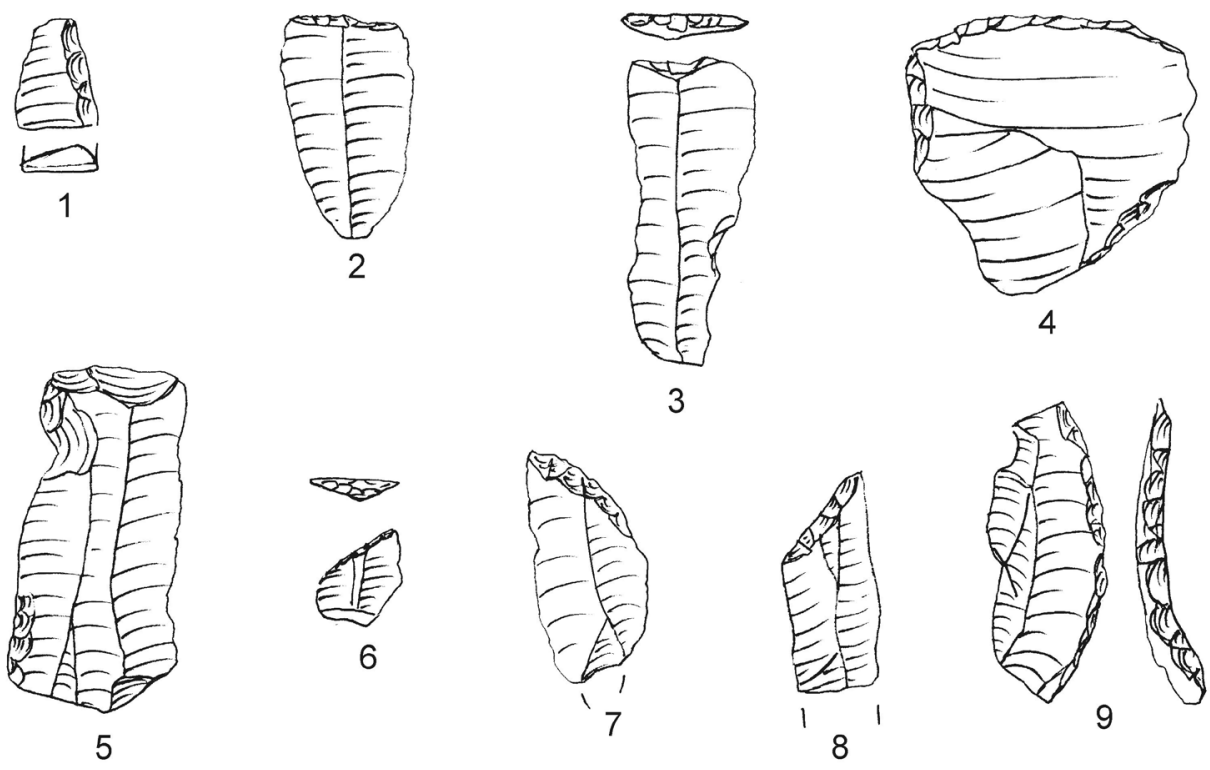

\section{3}
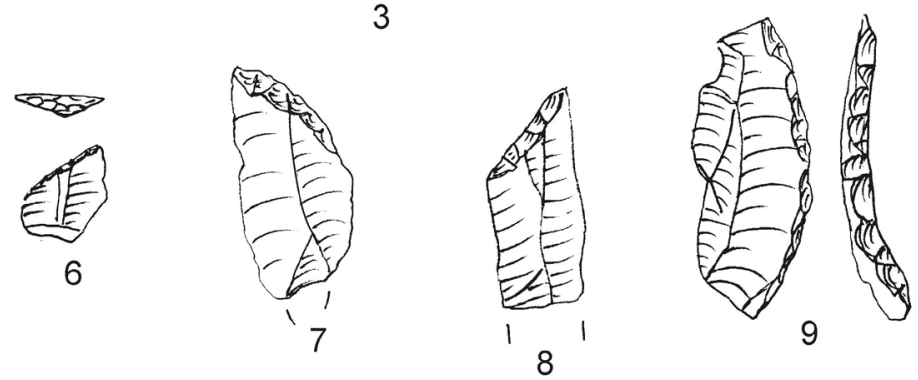

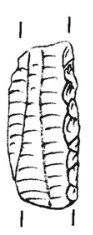

10

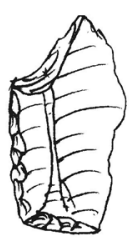

11

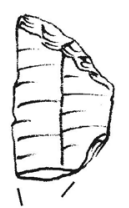

12

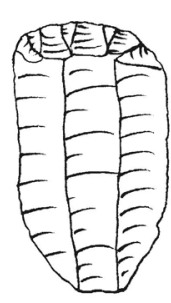

13
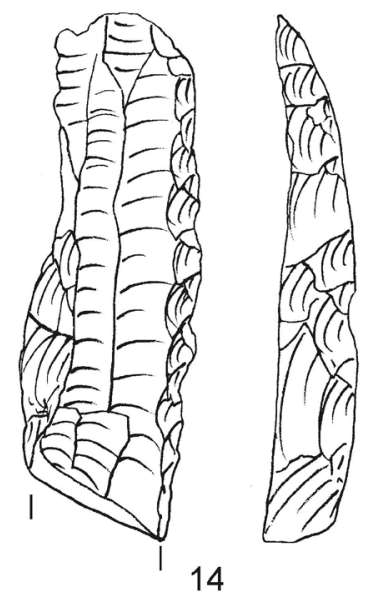

14

Pl. 6. 1-6. Konispol, Albania (according to Prendi 1990); 7-14. Putanja-Portonov, Albania

including end-scrapers, retouched bladelets and triangles (Miracle, ForenbaHER 1998). This assemblage has been dated to $8150 \pm 70$ BP. The inventory from Šupljata Cave was unfortunately mixed up and contained Epipalaeolithic components and Sauveterrian microliths (MALEZ 1979). Similarly the site of Abri Sebrn, which provided a fairly rich lithic inventory (more than 1000 artefacts, including 119 retouched tools), contained Final Palaeolithic and Mesolithic elements. The dates from this site span the period between 9360 and 8650 BP (КомŠо 2007). 

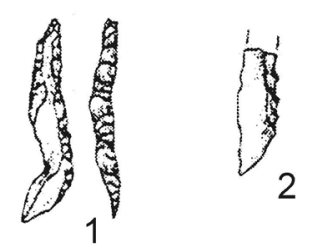

\%

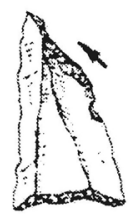

14

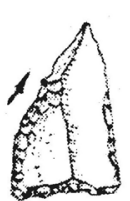

15

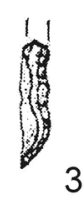

3
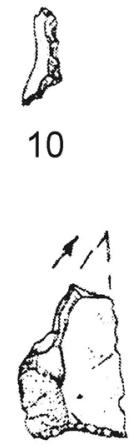

16
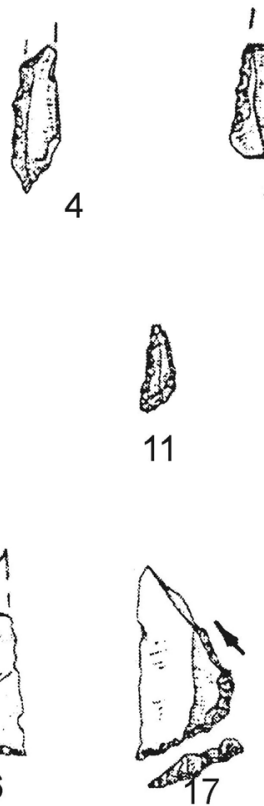
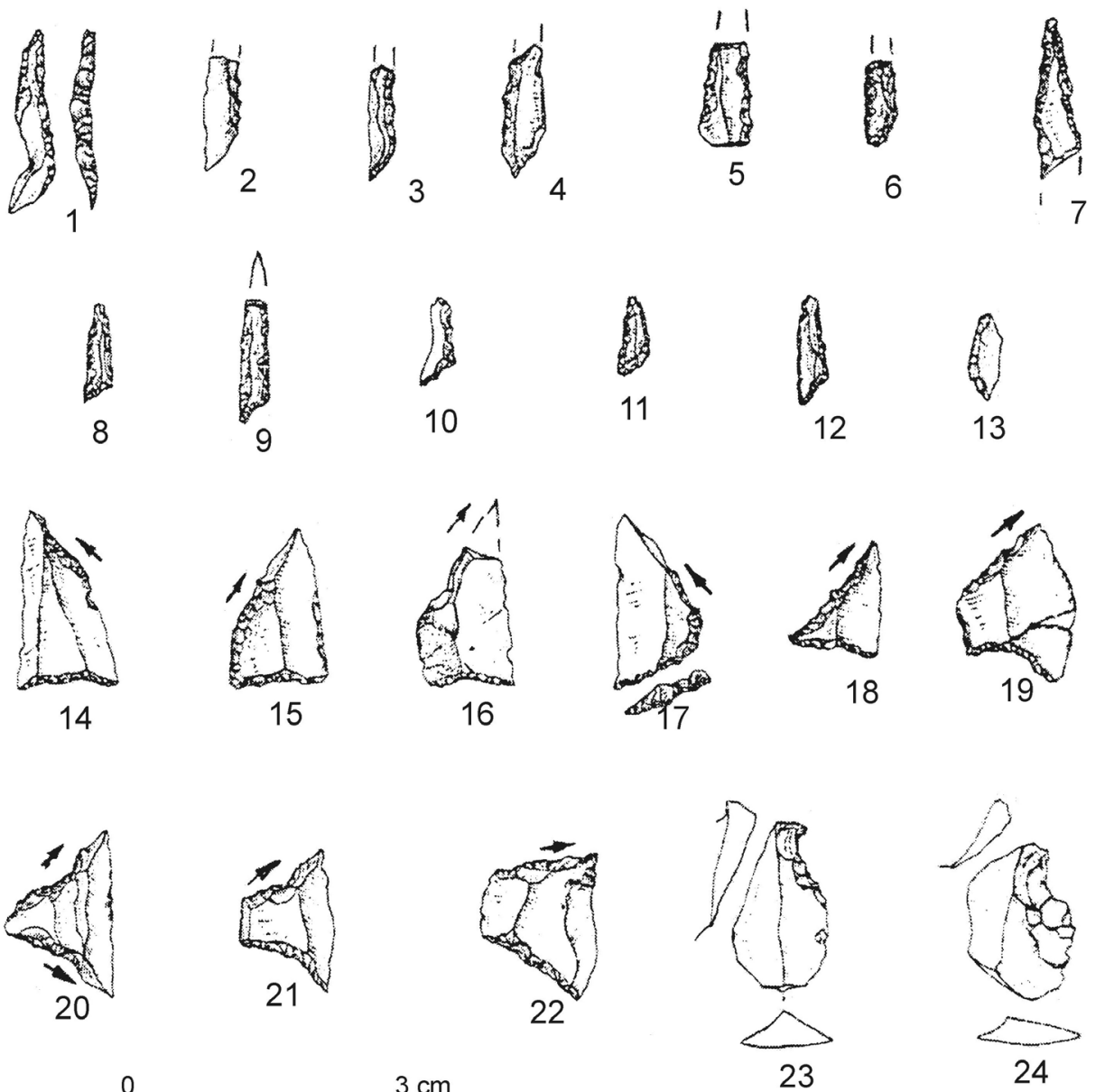

$3 \mathrm{~cm}$
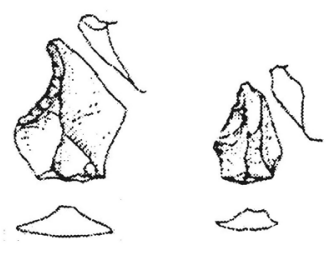

28

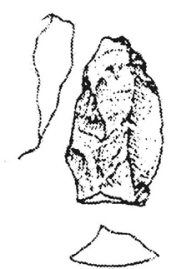

29

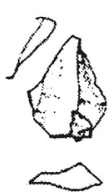

30

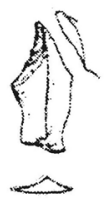

31

Pl. 7. 1-31. Pod Črmukljo, Slovenia (according to S. K. KozlowsKi 2009)

\section{The Castelnovian}

The inventories with Castelnovian elements in the eastern Adriatic zone are much more numerous than Sauveterrian assemblages. In Slovenia, sites with Epigravettian and Castelonovian components were registered. In the case of surface collections such as Dedkov Trebež (Pl. 3: 1-9) the co-occurrence of backed pieces, segments, and small triangles, 
together with Montbani bladelets, symmetrical and asymmetrical trapezes (KozŁOwSKI 2009) could be the result of the mixing of finds from different units. A similar situation could be found at the sites of Zamedvedca and Vrbicev Hrbec. The site of Breg layers 3-3a provided an Epigravettian/Castelnovian stratigraphic sequence (possibly with the latest date of 5900 BP - FreliH 1987; S.K. KozŁowsKi 2009). A complete Castelnovian sequence with four Mesolithic levels at a depth of 340-430 cm was registered at the site of Mala Triglavca (Petru 1997, 2004; TuRK (Ed.) 2004; S.K. KozŁowsKi 2009). All the levels contained asymmetrical trapezes $(\mathrm{Pl} .8: 1-3)$ produced by the microburin technique (Pl. 8: 6), rhombi (Pl. 8: 4), perforators, Montbani bladelets (Pl. 8: 5) and blade and sub-discoidal end-scrapers (Pl. 8: 8-14).

In the territory of Croatia, sites with Castelnovian elements are few. An open-air site of Lokve is the only one that can be attributed to the typical Castelonovian tradition. The site provided backed pieces, trapezes made using the microburin technique, truncations with a concave base, and numerous discoidal end-scrapers (Koмšo 2006).

A local variant of Castelnovian appears in Montenegrin cave sites, such as Crvena stijena and Odmut. At Crvena stijena the sequence of the Late/Final Palaeolithic Epigravettian layers (layers VII-V) and the Mesolithic layers with elements of the Castelnovian tradition (layers IVb2, IVb1 and IVa - BASLER 1975; MihaJlović 2001; Whallon (Ed.) 2017) were revealed. In the final Palaeolithic horizons discoidal end-scrapers in association with perforators, denticulate-notched tools and truncations predominated, whereas the Mesolithic levels yielded, first of all, flake inventories in association with Montbani bladelets, atypical perforators and fine flake end-scrapers. At the same time, it is evident that the technology of blanks production is typically Castelnovian throughout the entire level IV (FonTANA et al. 2016). Except for one specimen found during the most recent research, the microburin technique has not been recorded. All trapezes are made on simple broken blade segments (WHALLON ed. 2017). Along with classic trapezes there are short forms (MiHAJLović et al. 2017: fig. 10.31: 49, 50) which can also be doubled truncations.

As a classic example of a Late Mesolithic sequence, a similar variant of the Castelnovian tradition is the site of Odmut layers XD, Ia and Ib (J. K. KozŁowsKI et al. 1994). These layers produced a series of radiocarbon dates spanning from $9135 \pm 80$ to $7080 \pm 85$ BP (layer Ib), and $7350 \pm 160$ (layer Ia) (CRISTIANI, BorIĆ 2016). Throughout the layers the inventories exhibit a similar composition of artefacts, indicative of local stone processing: from cores (6-12.9\%), flakes (more than 60\%), blades (9.9-12.0\%) to retouched tools $(6-9 \%)$. In all the layers, tools included truncations (Pl. 9: 1-6), trapezes (Pl. 9: 7-14), and retouched blades (Pl. 9: 15-17), as well as single perforators (Pl. 9: 18-20) and backed pieces (Pl. 9: 21), including arched ones. The proportion of end-scrapers (Pl. 10: 1-9), mainly on flakes, was high (15-30\%). From this site a series of harpoons made from red deer antler is also known. The presence of harpoons in Odmut and Vruca indicates that the Mesolithic groups adapted their subsistence patterns to the local environment (CRISTIANI, Borić 2016).

The sequence of the Odmut Cave exhibits clearly the continuation of the Castelnovian tradition as far as the Neolithic levels with impresso and painted ceramics. 

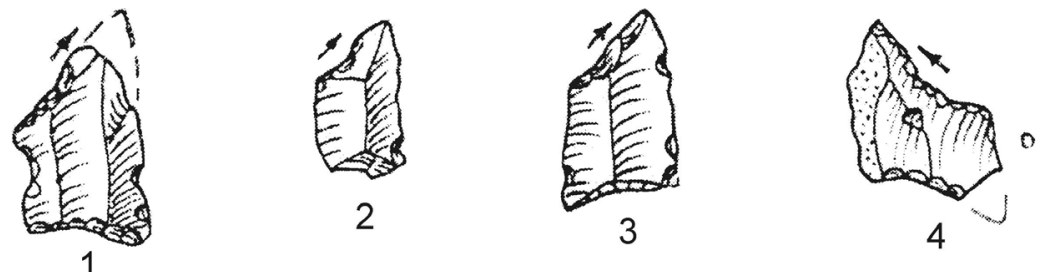

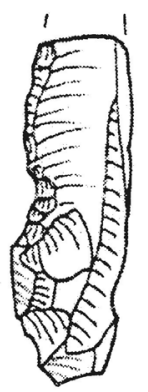

5

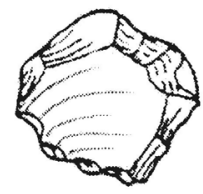

10
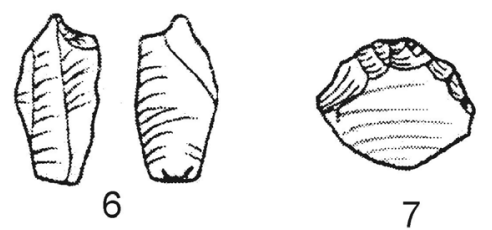

0

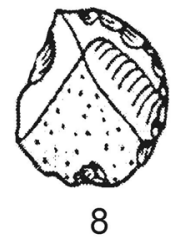

$3 \mathrm{~cm}$

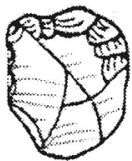

9

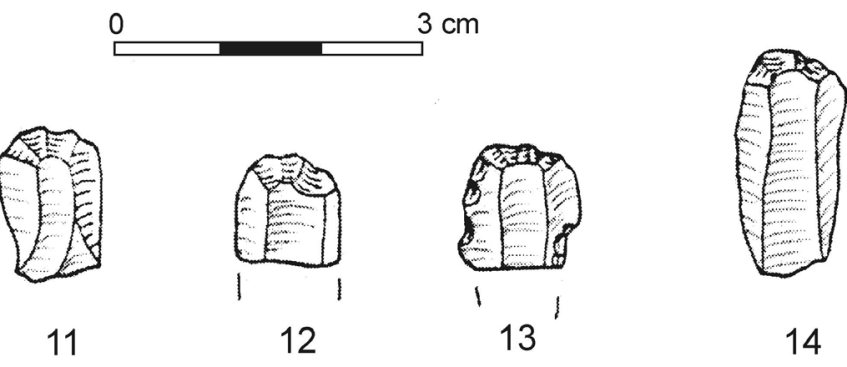

Pl. 8. 1-14. Mala Triglavca, Slovenia (according to S. K. KozLowsKi 2009)

Further to the south, the Castelnovian occurs in Albania at the site of Vlusha, where in a small trench two Late Mesolithic horizons with a Castelnovian-type industry were found. The inventories comprised of segments ( $\mathrm{Pl} .10$ : 10-15), arched backed pieces, end-scrapers on blades, a trapeze (Pl. 10: 16) and a perforator (Pl. 10: 17) (Prendi 1990; GJIPALI 2012).

\section{Flake-blade inventories}

Besides the aforementioned inventories attributed to the Late Pleistocene/Early Holocene, diverse assemblages with predominantly flake-blade technique occur on the eastern Adriatic coast. These sites produced no (or very little) diagnostic blade implements. These inventories can possibly be connected with a variety of site functions. However, it is also likely that they represent a separate, distinct cultural tradition, especially as most of them are territorially isolated. Sites like this were registered in Slovenia (Zalog near Verdu, KavUR 2006) and northern Bosnia, where the third level of the Rastuša Cave has been dated to $9700 \mathrm{cal}$ BP. It provided a flake industry with numerous denticulate-notched tools and retouched flakes (P1. 11: 1-5, 8) end-scrapers (Pl. 11: 6,7) including carenoidal items, and a backed piece with a convex blunted 


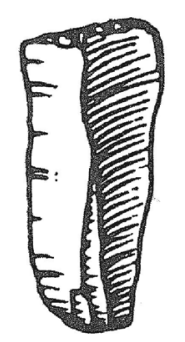

1
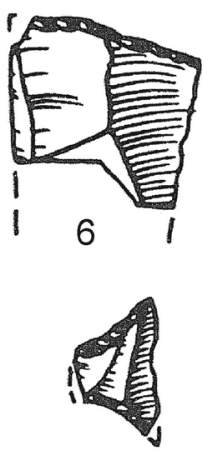

10
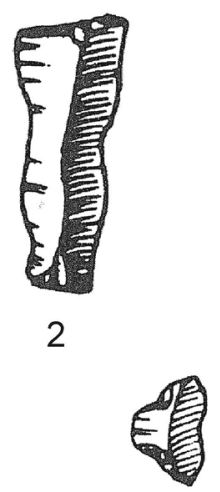

7

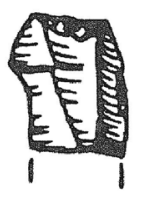

3

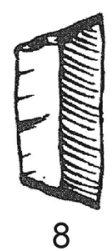
$3 \mathrm{~cm}$
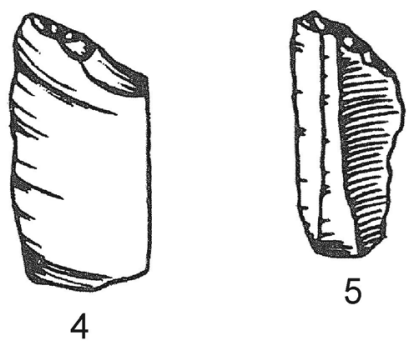

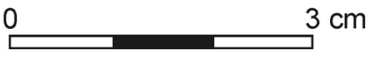

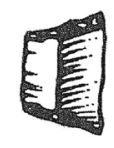

11

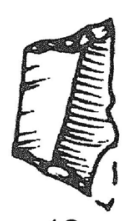

12

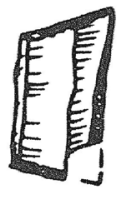

13

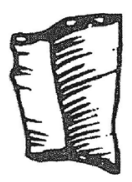

14

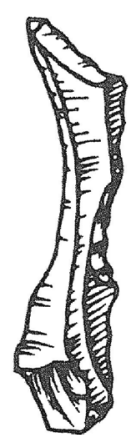

15

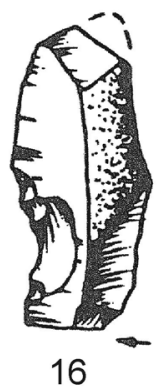

6

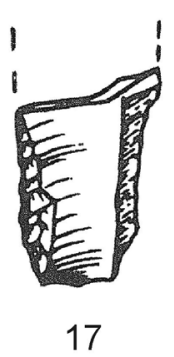

17
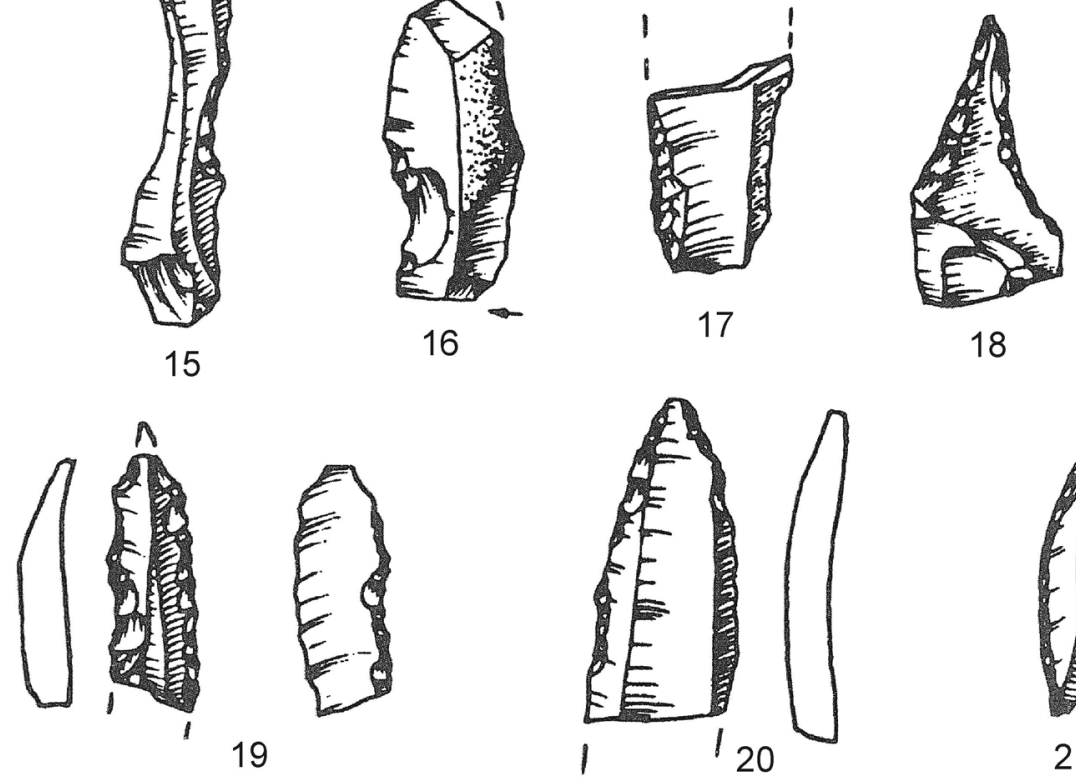

Pl. 9. 1-21. Odmut Cave, Montenegro

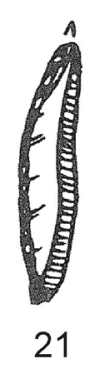



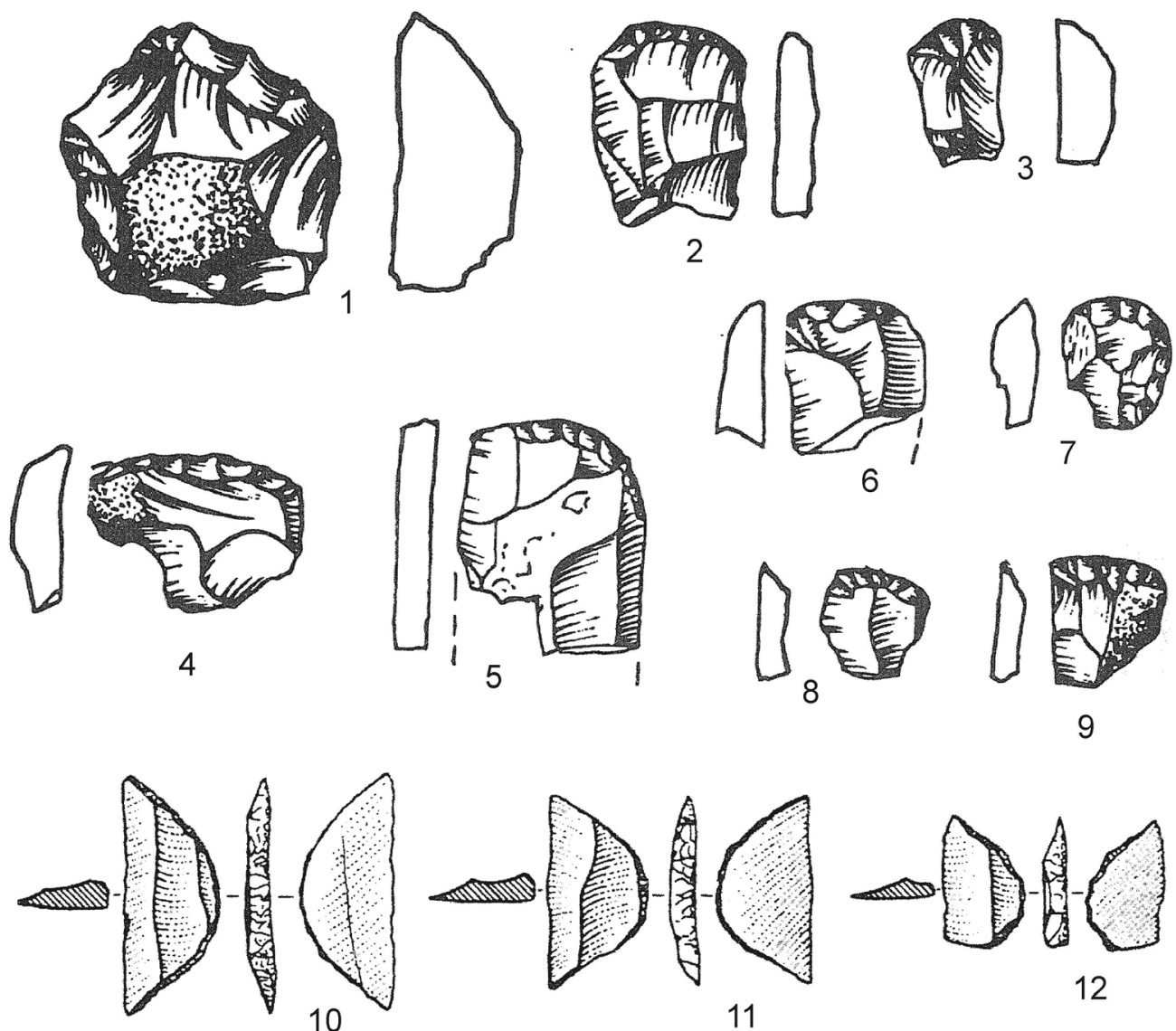

11

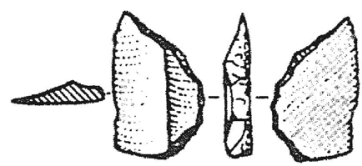

12

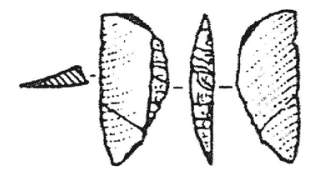

13

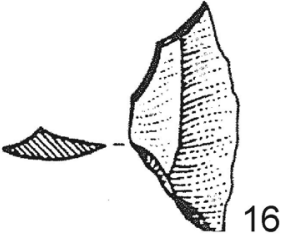

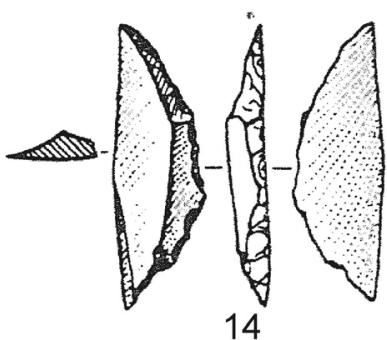

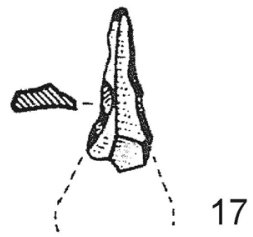

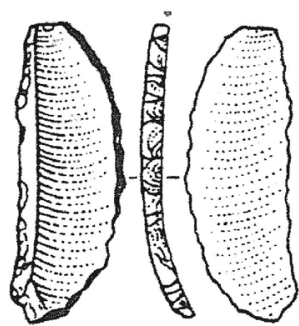

15 $3 \mathrm{~cm}$

Pl. 10. 1-9. Odmut Cave, Montenegro; 10-17. Vlusha, Albania (according to GJIPALI 2012) 

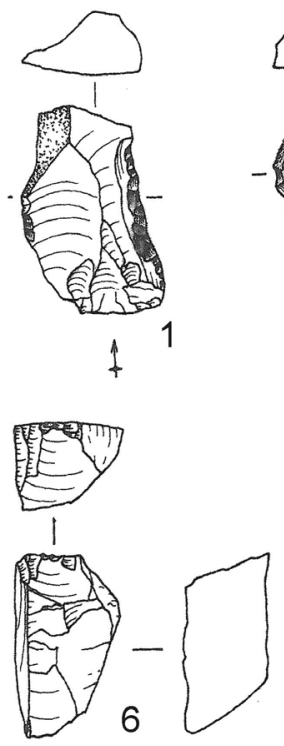

6
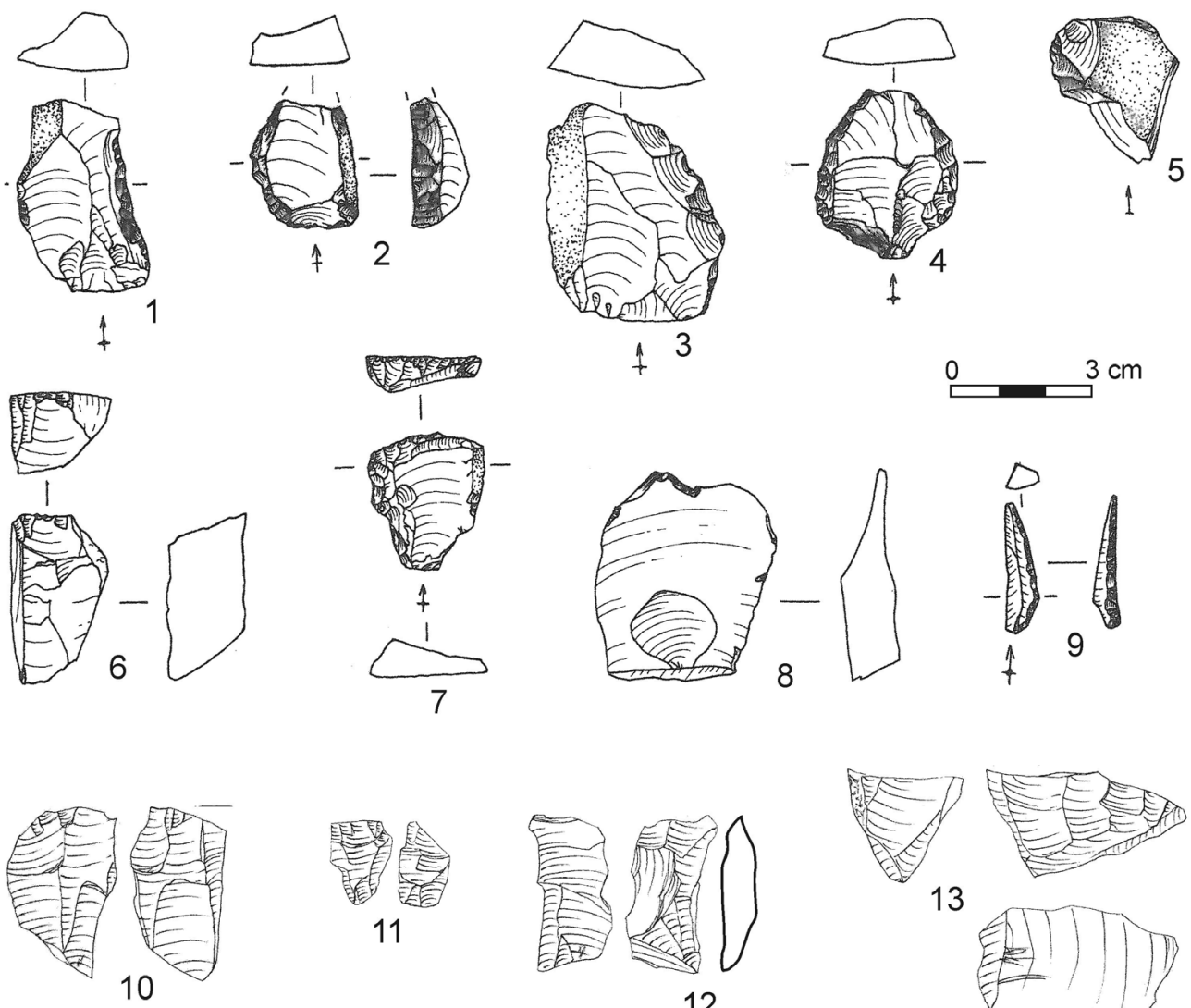

13

12

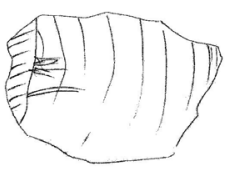

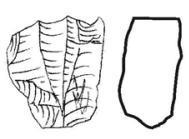

14

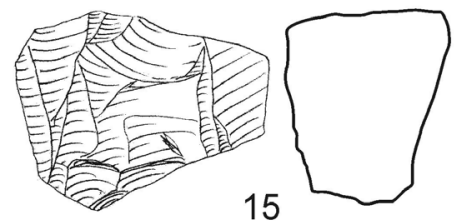

15

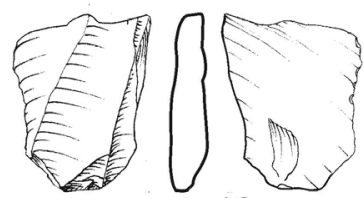

16

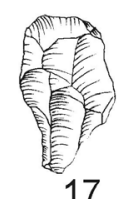

17

Pl. 11. 1-9. Rastuša Cave, Croatia (according to Jovanović et al. 2014); 10-17. Zemunica Cave, Croatia

back (Pl. 11: 9) (Jovanović et al. 2014). A. GASPARI and B. KAvUr (2006) consider Zalog as a special place where cervidae antlers were processed.

In Croatia similar sites include, for example, Vaganačka Cave (ForenBAHER, VRANIJCAN 1985) and Zemunica Cave (Pl. 11: 10-17, Pl. 12: 1-15), attributed by the excavators to the Epigravettian (Šošıć KLINDŽIĆ et al. 2015), and Velika Cave (MALEZ 1967). Regretfully, the dating of these sites is not reliable (Šošić KLINDŽIĆ et al. 2015). In the case of Mesolithic level C from Velika Cave the date of $5550 \pm 40 \mathrm{BC}$ seems too late.

In Montenegro, the multilayer site of Medena stijena provided a sequence spanning from the Palaeolithic (levels 10-5) to the Mesolithic (level 4 - MinaJlović 1996). 

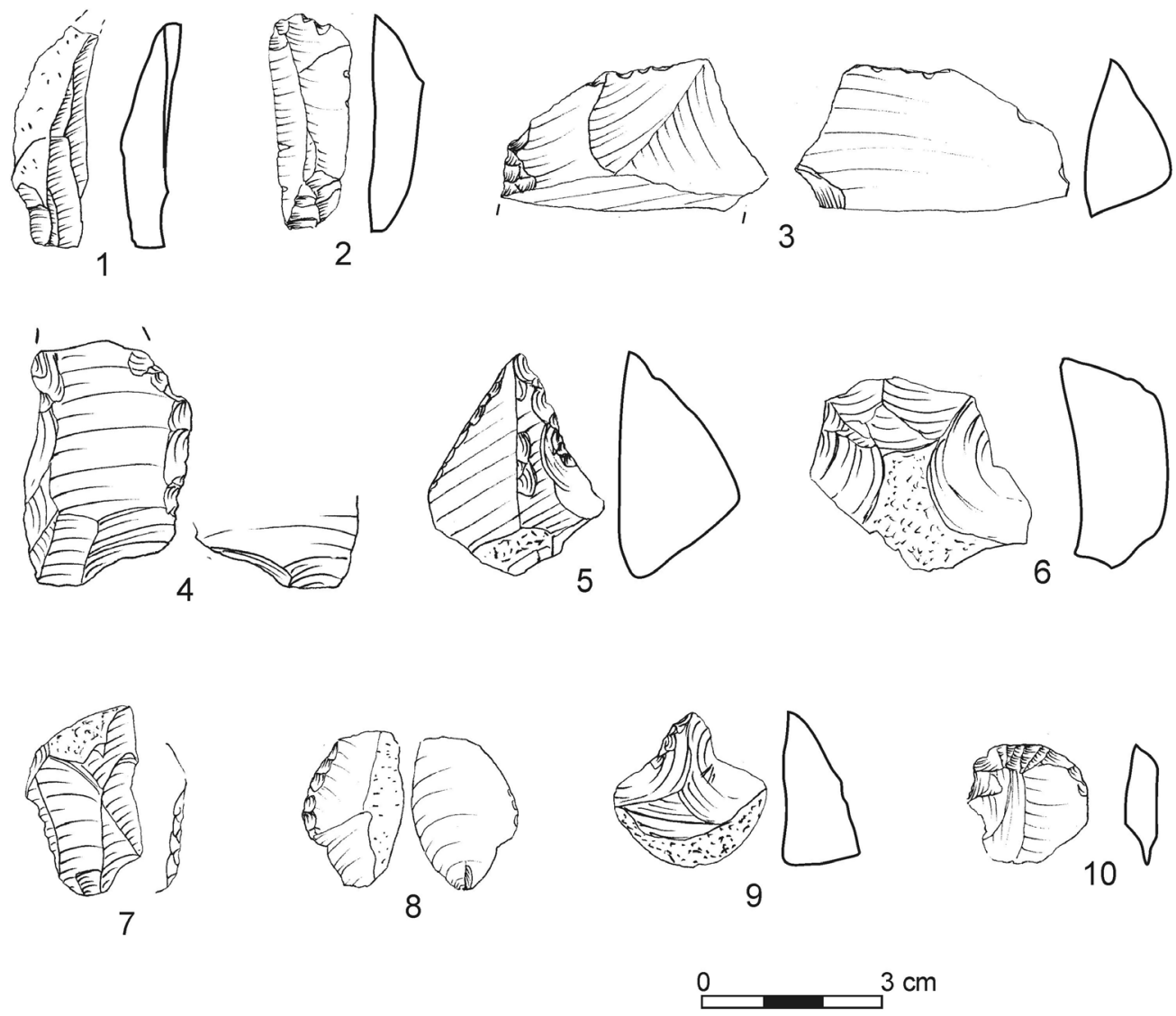

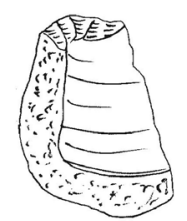

11

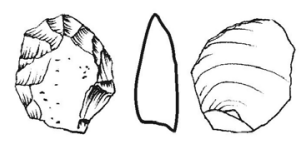

12

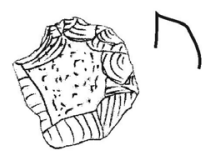

13

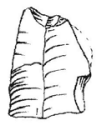

14

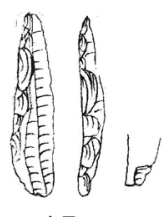

15

Pl. 12. 1-15. Zemunica Cave, Croatia

Along with retouched flakes, denticulate-notched tools and discoidal end-scrapers, level 4 at this site also produced low trapezes and perforators (Pl. 2: 20-26), but backed tools were absent.

In Albania, the site of Kryegata B provided a flake industry with numerous retouched flakes, but also individual trapezes and asymmetrical segments made without the use of the microburin technique (RunNels et al. 2004; KoRKUTI 2013).

A unique flake industry, possibly of different origin than industries at the Adriatic sites, was discovered by Sordinas (2003) at the site of Sidari on the island of Corfu. Apart from the standard flake technique based on single- and multiplatform cores (P1. 13: 1-4) a specific flake production was employed wherein 

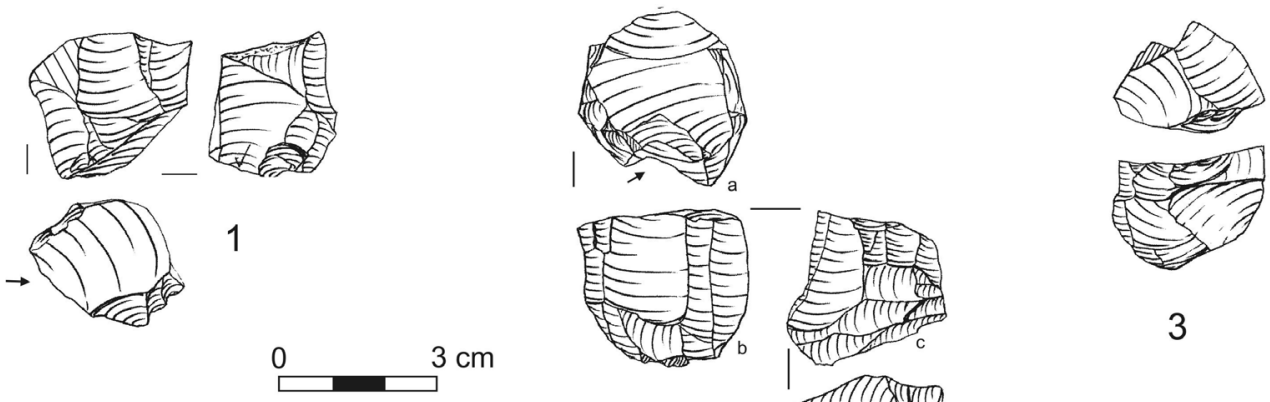

2

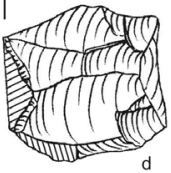

3
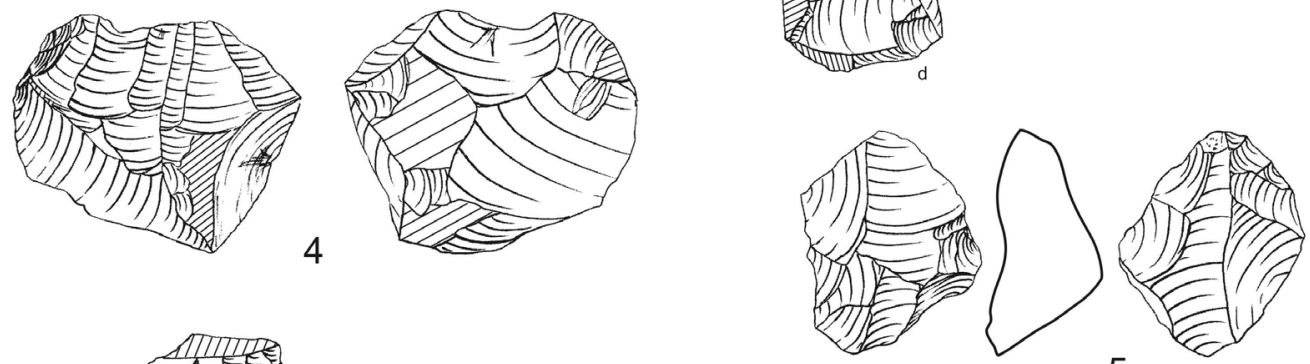

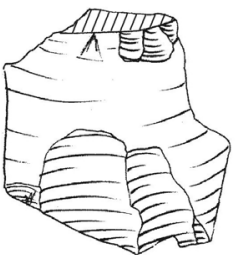

6

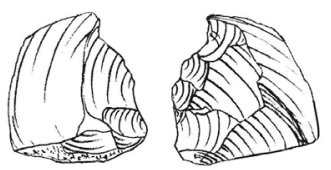

7

5

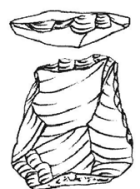

8
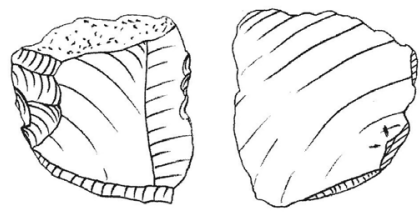

10

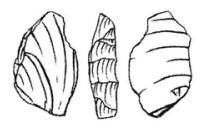

11

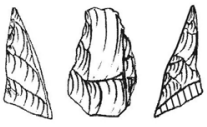

12
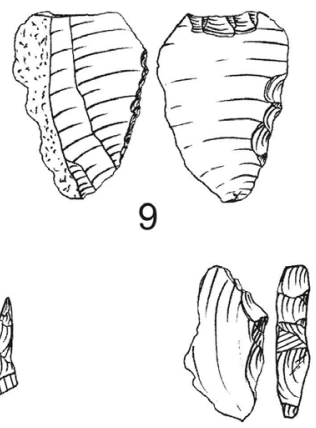

13

Pl. 13. 1-13. Sidari, Island of Corfu, Greece

flakes were consecutively detached from larger flakes (P1. 13: 5, 6). In addition to retouched flakes (Pl. 13: 7-10), robust, small backed pieces on flakes (Pl. 13: 11, 13) and atypical trapezes (P1. 13: 12) were also used as tools (KacZanowsKA, KozŁOWSKI 2014). 


\section{DISCUSSION}

Attempts to obtain a synthetic picture of the Mesolithic in the east Adriatic area meet with difficulties due to the incompleteness of sources resulting from environmental reasons (e.g. changing coastline in the Holocene) on one hand and the small number of sites explored using modern methods on the other. The observed discontinuities and gaps in development of particular taxonomic units may be objective, but may also stem from the factors mentioned above. In the area in question, a significant role was played by the Epigravettian component, which followed general patterns of cultural evolution in the Mesolithic (the increasing role of the flake technologies), while being at the same time affected by West Mediterranean influences (Sauveterisation and Castelnovisation). In certain cases these three tendencies overlapped, complicating the picture of the development of the Mesolithic in the eastern Adriatic area. The environmental diversity of this area may have favoured the rise of enclaves in which older traditions survived longer.

\section{CONCLUSIONS}

The belt of the eastern Adriatic coast opens up to the Adriatic Sea and Adriatic islands, while on the other side it is separated from the Central Balkans by the latitudinal range of the Dinaric Mountains. This range, up to $1500 \mathrm{~m}$ a.s.l., sometimes approaches and sometimes lies farther from the coast. In some areas, for example in Montenegro, the Dinaric range is intersected by canyon-like valleys which connect the river valleys flowing from north to south and the Adriatic. In the Mesolithic this opening towards the Adriatic Sea, particularly in the Early Holocene sea recession, was of the utmost importance for settlement processes and economies. The lower sea level facilitated trans-Adriatic contacts, mostly in the northern part of the Adriatic basin. The Early Holocene lower coastal line, however, meant that some Mesolithic sites are now submerged. An additional asset of the Adriatic coast was a large number of caves within the karstic sediments.

In the Mesolithic, in the specific geographical and environmental conditions of the Adriatic coast, a cultural province developed that was different from the cultures of the Central Balkans, and evidenced trans-Adriatic contacts. The study of techno-typological composition of lithic inventories made it possible to distinguish three cultural traditions: Epigravettian, Sauveterrian and Castelnovian.

The Epigravettian was distributed across the entire northern coast of the Mediterranean (KozŁowsKi, KaCZANOwsKa 2004) and shows several local developmental trends documented by the presence of multilayer, mainly cave, sites. The Epigravettian tradition persisted in the Early and Middle Mesolithic to disappear in the Late Mesolithic. However, sites are known where, apart from the Epigravettian tradition, Castelnovian influences are apparent. Accepting, after S.K. KozŁOWSKI (2009), a later chronology of the Castelnovian within the Mesolithic, and given the presence of assemblages with combined Epigravettian/Castelnovian elements, we can assume that in the eastern Adriatic coast the Epigravettian tradition persisted longer. 
An important element considered to be diagnostic for the Late Mesolithic are trapezes that constitute one of the diagnostic features of the Castelnovian. Trapezes in the function of inserts occur, however, in some regions e.g. Veneto, at sites as early as the Middle Epigravettian dated to Younger Dryas (Bus de la Lum - PERESANI et al. 1999-2000; Val Lastari - BRoglio 1992). In some cases it is doubtful whether such questionable items are true trapezes or double truncations. This puzzle can be resolved by technological and functional analyses (e.g. CRISTIANI et al. 2009), but - above all - by the association of these items with typical Castelnovian blades and trapezes. Early appearance of trapezes is registered in lithic phase VIII at the Franchthi Cave dated to between $8949 \pm 120$ and $8530 \pm 90$ BP (PERLÈs 1995). But these non-standard trapezes, sometimes with ventral retouches, resemble trapezes that appear later in the Rocadourian in France. The Sauveterrian is relatively rare at sites of the eastern Adriatic zone, and it merely indicates trans-Adriatic influences of the Sauveterrian from Central Italy.

The Castelnovian has been frequently discussed as a broader phenomenon (S. K. KozŁowsKi 2009) embracing the territories across France, as far as the Crimea. S. K. KozŁowski divides the Castelnovian into two provinces: the western, classical province (including Slovenia), and the eastern, Paracastelnovian province embracing the remaining part of the Adriatic coast and the Ionian Sea coast together with the southern Balkans. However, this division does not seem to be sufficiently grounded despite the fact that some sites in Montenegro e.g. Odmut Cave exhibit certain features that are not diagnostic for the Castelnovian (absence of the microburin technique, specific core types, and domination of end-scrapers and side-scrapers).

A separate tradition or functional specificity is represented by sites where flakeblade technology with individual inserts (mostly trapezes) dominates, while at the same time other diagnostic tools are absent.

At the turn of the Pleistocene and Holocene one can notice changes in lithic industries in the eastern Adriatic coast, with the growing role of the flake technologies. These changes were particularly noticeable in the southern part of the region. The process is linked by researchers (MIHAJLOVIĆ 2017) with the phasing out of specialised tools made on tiny blades in favour of more universal flake tools. This correlates with changes in subsistence strategies (MiHAJLOvić 2017).

In Slovenia and northern Croatia, the influence from west Mediterranean centres becomes more clearly visible in the early Holocene, which is evidenced by the presence of Sauveterrian and Castelnovian elements and the microburin technique. Further to the south, in Montenegro, these influences are less marked and the assemblages from this area are referred to as Paracastelnovian (KozŁowsKi et al. 1994) or an Adriatic variant of the Castelnovian technocomplex (MinaJlović 2017).

Flake assemblages identified in the eastern Adriatic coast may reflect the general technological tendencies or the functional differentiation connected, among other things, with environmental factors.

An important - and controversial - question is that concerning the relationship between the Late Mesolithic and the Neolithisation. Scholars (Franco 2011; Moore 2014) point to a hiatus between the last hunter-gatherers and first farmers in the 
Adriatic basin. However, there are sites where both radiocarbon dates and the development of lithic technologies suggest a direct succession of the Mesolithic and Early Neolithic (Odmut Cave, where the youngest Mesolithic level Ib dates to $7030 \pm 160$ BP and the earliest Neolithic level IIa to $6995 \pm 100$ BP (Cristiani, Borić 2016)).

Although the majority of arguments point towards the allochthonous genesis of the Neolithic, one cannot exclude that in some limited areas these two populations may have come into contact with each other.

ACKNowledgement. Thanks are due to the NCN (Polish National Research Centre) - grant no 2015/19/B/ HS3/00477.

\section{REFERENCES}

BaILey G. N. (Ed.), 1997. Klithi. Palaeolithic settlement and Quaternary landscapes in north-west Greece. T. 1, 2. McDonald Institute for Archaeological Research, Cambridge.

BaILEy G. N., 1999. The Palaeolithic archaeology and Palaeogeography of Epirus with particular reference to the Klithi rockshelter. In: Bailey G. N., Adam E., Panagopolou E., Perlès C., Zachos K. (Eds), The Palaeolithic Archaeology of Grecee and Adjacent Areas. Brithish School at Athens, Studies 3: 159-169.

Bailey G. N., Gamble C. S., 1990. The Balkans at 18,000 BP: the view from Epirus. In: Gamble C.S., Soffer O. (Eds), The World at 18,000 BP. Unwin-Hyman, London: 148-167.

Baković M., Mihailović B., Mihailović D., Morley M., Vušović-Lučić Z., Whallon R., Woodward J., 2009. Crvena stijena excavations 2004-2006, preliminary report. Eurasian Prehistory 6(1-2): 3-31.

BASLER Đ., 1975. Crvena stijena. Niksić.

Brodar M., 1992. Mezolitsko najdišče Pod Črmukljo pri Sembijah. Archeolożki Vestnik.

Brodar M., Osole F., 1979. Nalezišta paleolitskog i mezolitskog doba u Sloveniji. In: Benac A. (Ed.) Praistorija jugoslavenskih zemalja, vol. 1, Sarajewo: 135-158.

Broglio A., 1992. Mountain sites in the context of the north-east Italia Upper Paleolithic and Mesolithic. Preistoria Alpina 28/1: 293-310.

Broglio A., KozŁowski S. K., 1983. Tipologia ed evoluzione delle industrie mesolitiche di Romanano III. Preistoria Alpina 19: 193-148.

Broglio A., Lanzinger M., 1996. The human population of the southern slopes of the eastern Alps in the Würm late glacial and early postglacial. Il Quaternario 9(2): 499-508.

Cristiani E., Borić D., 2016. Mesolithic harpoons from Odmut, Montenegro: Chonological, contextual and techno- functional analyses. Qatenary International 423: 166-192

Cristiani E., Pedrotti A., Gianella S., 2009. Tradition and innovation between the Mesolithic and Early Neolithic in the Aduge valley (North-East Italy). New data from a fubctional and residues analyses of trapezes from Gaban rockshelter. Documenta Praehistorica 36: 191-205

ČEČUK B., 1986. Kopačina. Epipaleolitsko, mezolitsko i brončanodobno nalazište. Arheološki pregled 26: 32 .

ČEČUK B., 1996. Kopačina. Arheološki radovi i rasprave 12: 13-30.

Dimitriević S., 1998. Mezolitik ili sredniye kameno doba. In: Dimitriević S., Težak-Gregl T., Majnarić Pandžić N. (Eds), Prapovijest. Zagreb: 50-53. 
ĐuRČIĆ L. J., 1996. The chipped stone industry from the rock-shelter of Trebački krš. In: Srejović D. (Ed.) Prehistoric settlements in caves and roc-shelters of Serbia and Montenegro. Belgrad: 75-102.

Escalon De Fonton N., 1966. Du Paléolithique supérieur du Mésolithique dans le Midi Méditerranéen. Bulletin de la SPF LXII/1: 66-180

Fontana F., Flor E., Duches R., 2016. Technological continuity and disconuity in the Romagnano loc III rockshelter. Quaternary International 423: 252-265.

Franco C., 2011. La fine del Mesolitico in Italia. Identita culturale e distribuzione territoriale degli ultimi cacciatori-raccoglitori. Societa per la Preistoria e Protostoria della Regione Frijuli-Venezia Giulia 13: $1-279$.

FreLiH M., 1986. Breg pri Škofljici-mezolitsko najdišče na Ljubljanskem barju. Poročilo o raziskanju paleolita, neolita in eneolita v Slovenji 14: 21-57.

FreLiH M., 1987. Novo odkrita prazgodovinska plana najdišča na Ljubljanskem Barju. Poročilo o raziskanju paleolita, neolita in eneolita v Slovenji 15: 21-57.

Forenbaher S., VRanijCan P. 1985. Vaganačka pećina. Opuscula archaeologica: 10: 1-21.

GaSPari A., KaVur B., 2006. Zalog near Verd. Hunter's base camp on the shores of a lake? In: Gaspari A. (Ed.), Zalog near Verd. Stone Age hunters' camp at the western edge of the Ljubljansko barje. Opera Instituti Archaeologici Sloveniae 11: 199-204.

GJIPALI I., 2012. Epoka e Gurit dhe shqipëria. Tirana.

Jovanović I., Pandžić I., Miracle P. T., 2014. The chipped stone industry from Rastuša Cave. Banja Luka.

Kavur B., 2006. Stone tools. In: Gaspari A. (Ed.), Zalog near Verd. Stone Age hunters' camp at the western edge of the Ljubljansko barje. Opera Instituti Archaeologici Sloveniae 11: 45-124.

KомŠo D., 2003. Pećine Istre-mjesta življenja od prapovijesti do srednjeg Rijeka. Histria Antiqua 11: 41-54.

Kомšо D., 2006. Mezolitik u Hrvatskoj. Opuscula archaeologica 30: 55-92.

Kомšо D., 2007. Nakit sjevernog Jadana od paleolitika do kraja bakrenog doba. Situla 44: 31-40.

Komšo D., Miracle P. T., 2003. Test excavations in Moliniarska draga (NE Istria, Croatia). Histria Archeologica 34: 39-59.

Komšo D., Miracle P. T., 2005. Pećina Jačmica. Hrvatski Archeološki Godišnjak 1/2004: 150-152

Komšo D., Miracle P. T., 2006. Pupičina peć. In: Durman A. (Ed.), 100 hrvatskih arheoloških nalazišta, $222-223$.

Korkuti M., 2013. Archaeological studiem on the prehistoryk of Albania. Tirana.

Kaczanowska M., KozŁowski J.K., 2014. Foundation of the Neolithic Europe: the Mesolithic/Neolithic interface from the Aegean Basin to the Ionian/Adriatic baskin. Rocznik Polskiej Akademii Umiejętnosci $2013 / 2014$.

Kozlowski J. K., KaCZANOwska M., 2004. Gravettian /epigravettian sequences in the Balkans and Anatolia. Mediterranean Archaeology and Archaeomety 4(1): 5-18.

Kozıowski J. K., KozŁowski S. K., 1983. Le Mesolithique à l'est des Alpes. Prehistoria Alpina 19.

Kozıowski J. K., KozŁowski S. K., Radovanović I., 1994. Meso- and Neolithic sequence from the Odmut Cave (Montenegro). Warszawa.

Kozıowski S. K., 1999. The Eastern wing of the Fertile Crescent. BAR IS 780.

KozŁowski S. K., 2009. Thinking Mesolithic. Oxbow.

Lo Vetro D., Martini E., 2012. Il Paleolitico e il Mesolitico in Sicilia, Atti della XLI Riunione Scientiica dell'IIPP, 'Dai Ciclopi agli Ecisti: società e territorio nella Sicilia preistorica e protostorica', San Cipirello (Palermo), 2006: 19-48. 
Malez M., 1960. Pecine Čičarije i učke u Istri. Acta Geologica II: 163-260.

Malez M., 1967. Paleolit Velike pęcinę na Ravnoj gori u sjeverozapadnoj Hrvatskoj, Arheološki radowi i rasprave 4/5: 7-67.

Malez M., 1974. Nova dostignuča u istraživanjima paleolitika u nekim pečinama Hrvatske. Acta Carsologica VI/18: 259-270.

Malez M., 1979. Paleolitsko i mezolitsko doba u Hrvatskoj. In: Benac A. (Ed.), Praistorija jugoslavenskih zemalija. Sarajevo: 195-295.

MinajLović D., 1996. Upper Palaeolithic and Mesolithic chipped stone industries from the Rock-shelter of Medena stijena. In: Srejović D. (Ed.), Prehistoric settlements in caves and roc-shelters of Serbia and Montenegro. Belgrad: 9-60.

Minajlović D., 2001. Technological decline of the Early Holocene chipped stone industries in South-East Europe. In: Kertesz R., Makkay J. (Eds), From the Mesolithic to the Neolithic. Budapest: 339-348.

Minajlović D., 2017. Paleolithic-Mesolithic Crvena Stijena in relation to other sites. In: Whallon R. (Ed.), Crvena stijena in cultural and ecological context. Multidisciplinary Archaeological Research in Montenegro. National Museum of Montenegro, Montenegrin Academy of Sciences and Arts, Podgorica.

Minajlović D., Minajlović B., 2007. Considérations sur le Gravettien et l'Epigravettien ancient aux Balkans de l'Ouest. Paléo 19: 115-129.

Mihajlović D., Mihajlović B., Whallon R., 2017. Excavations of Middle Paleolithic-Mesolithic layers. In: Whallon R. (Ed.), Crvena stijena in cultural and ecological context. Multidisciplinary Archaeological Research in Montenegro. National Museum of Montenegro, Montenegrin Academy of Sciences and Arts, Podgorica: 150-205.

Miracle P.T., Forenbaher S., 1998. Pupićina Cave Project: brief summary of the 1998 sezon. Histria archaeologica 29: 27-48.

Miracle P.T., Forenbaher S., 2006. Prehistoric Herders in Istria (Croatia). The Archaeology of Pupićina Cave, Vol 1 (Monograph series 14 - Archaeological Museum of Istria).

MLEKuŽ D., 2001. Floods and fires: Landscape dynamics at Ljubljana Moor, Slovenja. In: Fewster K. J., Zvelebil M. (Eds), Ethnoarchaeology and hunter - Gatherers: pictures at an exhibition. BAR Interacional Series 955: 43-52.

Montet-White A., KozŁowski J. K., 1983. Les industries à pointes à dos dans les Balkans. Rivista di Scienze Preistoriche 38: 371-399.

Moore A. M. T., 2014. The spread of farming to the Adriatic: new insight from Dalmatia. Eurasian Prehistory 11/1-2: 155-164.

Palma Di Cesnola A., 1993. Il Paleolitico superiore in Italia. Firenze.

Palma Di Cesnola A., 2005. Paglici. L’Aurignaziano e il Gravettiano antic. Foggia.

Paunović M., Karavanić I., 1997. The Quesition of the Epipaleolithic and Mesolithic in Croatia. In: Bintz P. (Ed.), L' Europe des derniers chasseurs, Actes V. congres of Prehistoric and Protohistoric Sciences (UISPP), Paris 1995: 399-404.

Perlès C., 1995. La transition Pleistocène/Holocè et le problème du Mésolithique en Grèce. In: Villaverde Bonilla V. (Ed.), Los ultimos cazadores. Alicante: 179-209.

Petru S., 1997. Methods of research on use wear on the stone tools from the sites of Zakajeni spodmol and Mala Triglavca. Poročila o raziskanju paleolita, neolita in eneolita Slovenjie, 24: 79-97.

Petru S., 2004. Usewear analysis of Mesolithic and Neolithic stone tools from Mala Triglavca, Trhlovca and Pupičina peč. Documenta Praehistorica 31: 199-204.

Peresani M., Bertola S., De Stefani M., Anastasio G., 1999-2000. Bus de la Lum and the Epigravettian okupation of the Venetian pre-Alps during the Younger Dryas. Rivits di Science Preistoriche L: 103-132. 
Prendi F., 1990. Le Néolithique ancien an Albanie. Germania 68(2): 399-426.

Ruka R., Gjipali I., Galaty M.L., Baj Ramaj N., 2014. Lithic At one end of the Circum-Adriatic: case studiem from the southernmost Albanian coastal lowland. Proceedings of the International Congress of Albanian Archaeological Studies: 93-106.

Runnels C., Korkuti M., Galaty M., Timpson M., Stocker S.H., Davis J., Bejko L., Muçuaj S., 2004. The Palaeolithic and Mesolithic of Albania: survey and excavations at the site of Kryegjata B (Fier district). Journal of Mediterranean Archaeology 17(1): 3-29.

Sordinas A., 2003. The 'Sidarian' maritime Mesolithic non-geometric microliths in western Greece. In: Galanidou N., Perlès C. (Eds.), The Greek Mesolithic. British School in Athens 10: 89-97.

Schuldenrein J., 1998. Konispol Cave, southern Albania, and correlations with other Aegean Caves occupied in the Late Quaternary. Geoarcheology 13(5): 501-526.

Šošić-Klindžić R., Radović S., Težak-Gregl T., Šlaus M., Perhoč Z., Altherr R., Hulina M., Gerometta K., Boschian G., Vukosavljević N., Ahern J.C..M., Janković I., Richards M., Karavanić I., 2015. Late Upper Palaeolithic, Early Mesolithic and Early Neolithic from the cave site Zemunica near Bisko (Dalmatia, Croatia). Eurasian Prehistory 12(1-2): 3-46.

TuRK I., 2004. (Ed.). Viktorjev spodmol and Mala Triglavca. Instituti Archaeologici Slovenja, Lublana.

Turk M., Mlinar M., Turk J., BizJak J., Jamnik P., 2005. Plano Mezolitsko najdišče na planini Pretovč. Arheološki vestnik 56: 37-47.

Vukosavkjević N., Karavanić I., 2015. Arheologija špilje Zale. Modruš.

Whallon R. (Ed.)., 2017. Crvena stijena in cultural and ecological context. Podgorica. 